\title{
Kerogen: from Types to Models of Chemical Structure
}

\author{
M. Vandenbroucke ${ }^{1}$ \\ 1 Institut français du pétrole, division G éologie-G éochimie, 1 et 4, avenue de Bois-Préau, 92852 Rueil-M almaison Cedex - France \\ e-mail: mireille.vandenbroucke@ifp.fr
}

\begin{abstract}
Résumé — Les kérogènes : de la notion de types aux modèles de structure chimique — Le but de cet article est de présenter, à travers une revue des développements conceptuels et analytiques en géochimie dans la période 1970-1990, les principales étapes qui ont conduit, à travers la préparation et l'analyse des kérogènes d'une part, et l'étude de systèmes pétroliers de référence d'autre part, aux notions de types, chemins d'évolution et modèles statistiques de structure chimique des kérogènes.

Le kérogène est défini comme la matière organique des sédiments qui produit le pétrole, opposant ainsi le pétrole, soluble dans les solvants organiques courants, à son complément insoluble. Ce kérogène étant une matière organique complexe intimement mélangée aux minéraux des sédiments, la première tâche a été de mettre au point un protocole fiable pour son isolement, permettant ensuite son étude par des méthodes physicochimiques variées. En parallèle, le développement des permis d'exploration pétrolière, donnant accès aux échantillons de forage, permettait la comparaison géochimique de divers systèmes pétroliers. Les comparaisons furent faites non seulement entre les compositions chimiques des huiles, roches mères et kérogènes, mais aussi sur l'époque de production du pétrole. La notion de cinétique de craquage du kérogène en pétrole résultant de ces études de systèmes pétroliers, associée à l'observation d'une compensation des facteurs temps et température, conduisit à utiliser la pyrolyse en laboratoire pour évaluer le potentiel pétrolier restant à produire par le kérogène, et donc, à la construction de l'appareil Rock-Eval. Au milieu des années 1970, les principaux paramètres géochimiques des kérogènes de certaines séries pétrolières de référence étaient disponibles pour la définition des notions de type et de chemin d'évolution des kérogènes au cours de l'enfouissement géologique des sédiments.

Un pas important dans la connaissance de la composition chimique du kérogène fut franchi dans les années 1980 avec l'utilisation de nouvelles techniques de pyrolyse analytique et préparative, et leur couplage avec différents détecteurs. Les produits de pyrolyse, considérés comme briques élémentaires issues du craquage thermique du kérogène, pouvaient ainsi être analysés et quantifiés au niveau moléculaire, sans les problèmes de représentativité rencontrés avec l'analyse des extraits naturels et dus aux pertes de composés volatils et de produits ayant migré hors des roches mères. Le développement parallèle de la résonance magnétique nucléaire $\mathrm{du}^{13} \mathrm{C}$ en phase solide permit l'analyse et la quantification des diverses formes du carbone et de son environnement chimique dans le kérogène, ce qui n'était pas possible auparavant sous forme quantitative par la spectroscopie infrarouge ou ultraviolette. L'analyse quantitative des briques moléculaires et des groupes fonctionnels qui les assemblaient dans le kérogène permit ainsi d'élaborer des modèles moléculaires statistiques de kérogènes dans le but de visualiser l'ensemble de leur composition atomique et moléculaire, ainsi que les changements de composition liés aux types et à la maturité géologique. Il ne sera jamais possible de représenter une structure réelle de kérogène, tout simplement parce que le kérogène est un mélange de macromolécules variées, et non de polymères, et donc leur analyse individuelle est impossible. Cependant, une structure hypothétique
\end{abstract}


moyenne, prenant en compte un grand nombre d'informations issues d'analyses variées, permet de visualiser de façon synthétique les principales ressemblances et différences entre les matières organiques sédimentaires.

\begin{abstract}
Kerogen: From Types to Models of Chemical Structure - The aim of the present paper is to review the conceptual and analytical developments in the period 1970-1990 which have led, through kerogen isolation and analysis on one hand, and case studies of petroleum systems on the other hand, to the concept of kerogen types, evolution paths, and statistical chemical models.

Kerogen is defined as the sedimentary organic matter generating petroleum, an insoluble product as opposed to its counterpart soluble in usual organic solvents, such as petroleum. As kerogen is a complex organic material intimately mixed with minerals in sediments, the first task was to set up a robust procedure for its isolation, enabling then its study by various physicochemical analyses. The parallel development of oil exploration, resulting in geological sample availability, made the geochemical comparison of various petroleum systems possible. Comparisons concerned not only oils, source rock extracts and kerogen compositions, but also the timing of petroleum generation. The notion of kinetic cracking of kerogen into petroleum stemming from these case studies, associated with the observation of time and temperature compensation, resulted in the use of pyrolysis to evaluate the oil potential still to be generated by the kerogen, and in the construction of the Rock-Eval. In the mid 70s, all main parameters on kerogens from reference series of source rocks were available to define the notions of types and evolution paths of kerogens upon geological maturation.
\end{abstract}

A further important step for improving the knowledge of kerogen composition was achieved in the 80s using new techniques of analytical and preparative pyrolysis and their coupling with different detectors. The pyrolysis products, small building blocks issued from the kerogen thermal cracking, could thus be analyzed and quantified at the molecular level, without the problems of representativity associated with natural extract analyses, such as loss of volatile fractions or product migration out of source rocks. Contemporaneous developments in solid state ${ }^{13} \mathrm{C} N M R$ allowed quantification of the various forms of carbon and their molecular environment in the kerogen, whereas quantification was not possible with IR or UV spectroscopy. The quantification of molecular building blocks and their bonding functional groups in kerogens allowed conceptual averaged molecular models of kerogens to be proposed in order to visualize their atomic and molecular composition, and the changes occurring in this composition according to types and maturity. Although it will never be possible to represent a true kerogen structure, simply because it is a mixture of various nonpolymeric macromolecules, an hypothetical average structure of kerogen, representing a large amount of information from various analyses, can provide a synthetic view of the main resemblances and differences among sedimentary organic matters.

\section{IN TRO DUCTION}

Kerogen is defined as the insoluble sedimentary organic matter capable of generating petroleum. The fact that this sedimentary organic matter is usually intimately mixed with minerals during its deposition was of course a source of difficulties because its physical isolation, or at least concentration, was required before analysis, a problem that did not arise for coal studies. The onset of research work in coal science and organic geochemistry also aimed at different industrial objectives, downstream projects with gasification and liquefaction for coal, upstream projects with petroleum exploration for kerogen. For these reasons chemical studies on coal began much earlier than those on kerogens, with the publication of a major textbook, Coal, by van Krevelen in 1961, whereas at the same period the main efforts on kerogen were devoted to development and comparison of isolation methods (Forsman, 1963). Without minimizing the impact of these early papers and geochemistry books on the progressive understanding of benefits that petroleum exploration would draw from organic geochemistry studies, the publication of a major textbook on the origin and occurrence of petroleum, by B. Tissot and D. Welte, occurred in 1978, and the corresponding textbook on kerogen, edited by B. Durand, was published in 1980.

The aim of the present paper is thus to review the main steps of conceptual and analytical developments in organic geochemistry during the period 1970-1990 which have led, through kerogen isolation and analysis on one hand, and case studies of petroleum systems on the other hand, to the concept of kerogen types, evolution paths, and chemical structural models. Although kerogen is also a major sink in the global carbon cycle, the processes of kerogen formation in present and past geological times, in other words the mechanisms of transformation and selective preservation of the organic matter finally incorporated into sediments, will 
not be discussed in this paper. Indeed these topics are still a matter of debate and active research. Despite numerous advances in knowledge of kerogen precursors, many important points are still far from being elucidated.

\section{DEFIN ITION AND ISO LATION OF KEROGEN}

\subsection{Usual Definition and Related Ambiguities}

\subsubsection{The Broadening of Successive Kerogen Definitions}

The word kerogen was coined by Crum-Brown (1912) and used to describe the organic matter of a Scottish oil shale that produced a waxy oil upon distillation (keros = wax). This definition was thus restricted to low maturity organic-rich rocks of economic importance. Further on, recognizing that organic matter in sedimentary rocks, even at concentrations ranging around $1 \%$, can generate oil either by artificial pyrolysis or by burial for long periods of time, White (1916), then Trager (1924), both cited by Durand (1980), extended this early economic definition to all organic matter in rocks capable of oil generation.

It should be noted that this conceptual definition implies that kerogen and petroleum have complementary characteristics, as recognized by Forsman and Hunt (1958). Accordingly, petroleum being soluble in usual organic solvents, they defined in turn kerogen as the sedimentary organic matter insoluble in these solvents. However, even this now largely accepted operational definition leads to a whole range of different procedures aiming at physical or chemical concentration or isolation of kerogen, as discussed below.

The definition of Forsman and Hunt was later extended by Durand (1980) to all insoluble sedimentary organic materials, including not only materials dispersed in sedimentary rocks but also almost "pure" organic deposits such as humic and algal coals, as well as the insoluble organic matter from recent sediments obtained after removal of the humic fraction that is soluble in aqueous basic solutions. The rationale is that all these substances represent various types of sedimentary organic matter and/or different stages of its transformation process after geological burial.

\subsubsection{Ambiguities Resulting from the Definition of Kerogen}

It is important to keep in mind that the name kerogen, in opposition with usual chemistry nomenclature, does not represent a substance with a given chemical composition. Indeed kerogen is a generic name, in the same sense as lipids or proteins. Several organic precursors and their mixtures may lead to kerogen incorporation in sediments. Moreover, with geological burial of sediments at temperatures ranging from a few tens to less than $200^{\circ} \mathrm{C}$, during time periods from tens to thousands of million years, the chemical composition of kerogen dispersed in sedimentary layers (called source rocks) progressively changes, a part of it being transformed into petroleum and gas. The operational definition of kerogen on the basis of insolubility accounts neither for these compositional variations due to source and evolution, nor for a possible mixture of the substance able to generate petroleum with other insoluble organic compounds like coke for example, resulting from further petroleum transformation into source rocks.

Another major drawback of the pragmatic definition of kerogen by its insolubility in organic solvents, in contrast with oils or bitumens solubility, is that the composition and chemical features of kerogen will be closely dependent on the organic solvent and extraction procedure used for this separation. As a consequence, analytical data on kerogens can be compared only if the same solvent is used. Unfortunately, there are no established standard protocols regarding extraction procedures, either in terms of the solvent polarity or for sample grinding, temperature, duration of extraction and stirring efficiency. The result is that extraction can never be considered as "complete" since any change in these parameters may result in extraction of further compounds. Polar solvents used in the past, such as chloroform, mixtures of benzene and methanol, or pyridine frequently used by coal scientists, have been almost completely abandoned now due to their high toxicity. Petroleum geochemists use generally slightly polar solvents with rather low boiling points, and most often dichloromethane, sometimes mixed with methanol. The reason for choosing this type of solvent is that bitumen resulting from kerogen transformation in source rocks contains mainly hydrocarbons, representative of major components of crude oils, most of which can be efficiently extracted with such solvents and further analysed by a variety of analytical methods.

Beside solvent extraction needed for separation of soluble and insoluble organic matter in rocks, analytical techniques used for kerogen characterization often require its isolation from minerals, or at least its concentration. This can be done by more or less efficient physical or chemical methods. A review of these different procedures can be found in Forsman (1963), Robinson (1969), Durand and Nicaise (1980), and for the most recent ones in a review paper on kerogen (Vandenbroucke and Largeau, in press). In consequence, only the usual chemical procedure set up at IFP will be described here.

\subsection{IFP Chemical Procedure for Kerogen Isolation}

\subsubsection{Basic Principles of the Kerogen Preparation}

This procedure was designed by Durand and Nicaise (1980) on the basis of previous work by Forsman and Hunt (1958) and Saxby (1970), and its flowchart is presented on Figure 1. 


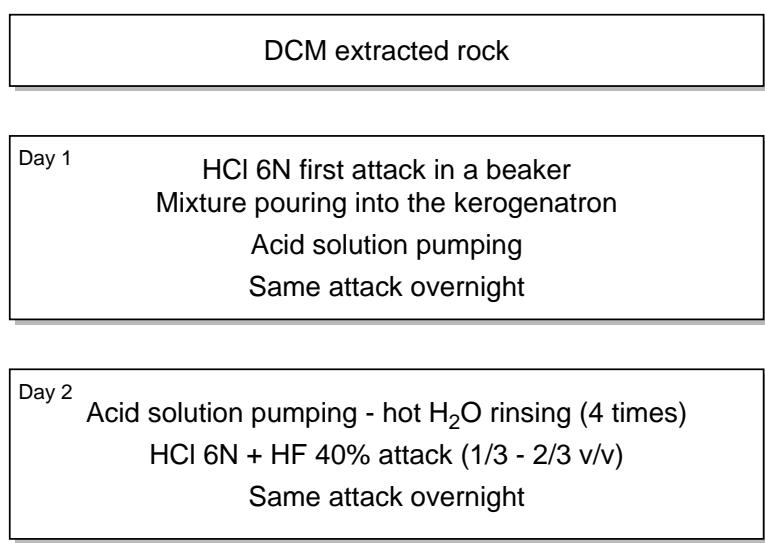

Day 3

Acid solution pumping - hot $\mathrm{H}_{2} \mathrm{O}$ rinsing (1 time) $\mathrm{HCl} 6 \mathrm{~N}$ attack $(4 \mathrm{~h})$

Hot $\mathrm{H}_{2} \mathrm{O}$ rinsing (6 times at least and up to neutrality) Kerogenatron opening and kerogen recovery with $\mathrm{H}_{2} \mathrm{O}$

Day $4 \quad$ Drying at $100^{\circ} \mathrm{C}$ under $\mathrm{N}_{2}$ flow

Day 5 Recovery of dry organic matter - grinding Extraction with DCM

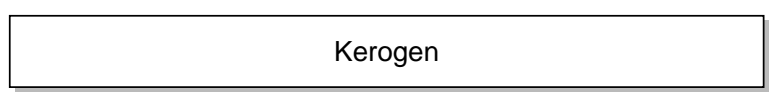

Figure 1

IFP procedure for kerogen isolation.

It is based on the destruction of major minerals from the finely ground sedimentary rock by nonoxidant acid attacks at temperatures between 60 and $70^{\circ} \mathrm{C}$ under an inert atmosphere, in order to prevent any oxidation of kerogen during preparation. Carbonates, sulfides, sulfates and hydroxides are first destroyed by two successive attacks with $6 \mathrm{~N}$ hydrochloric acid, then clay minerals, quartz and silicates are destroyed also by two successive attacks using a mixture of $40 \%$ hydrofluoric and $6 \mathrm{~N}$ hydrochloric acids (resp. 1/3 and $2 / 3 \mathrm{v} / \mathrm{v})$. Each first acid attack lasts $4 \mathrm{~h}$, and the second acid attack is performed overnight. In defining the analytical procedure, some minerals were observed to remain as residues with kerogen after these acid attacks. Two classes of resistant minerals were recognized by the authors cited above: firstly, newly formed fluorides resulting from the hydrofluoric acid attack such as ralstonite $\mathrm{Na}_{\mathrm{x}} \mathrm{Mg}_{\mathrm{x}} \mathrm{Al}_{2-\mathrm{x}}(\mathrm{FOH})_{6} \mathrm{H}_{2} \mathrm{O}$ and other complex fluorides (Robinson, 1969; Durand and Nicaise, 1980); secondly, minerals resisting these acids, mainly pyrite but also minor heavy oxides such as zircon, rutile and anatase. The newly formed fluorides are complex and very difficult to redissolve once precipitated. Since they interfere with further analysis of kerogen, it is important to prevent their formation. According to Durand and Nicaise (1980), the best way to do so is first to perform several thorough rinsings with hot distilled water between acid attacks without filtering the residue to dryness, in order to eliminate a maximum amount of cations. A second and very important step of the preparation, forgotten by many users of this procedure, is to perform a new $6 \mathrm{~N}$ hydrochloric attack during $4 \mathrm{~h}$ after the $\mathrm{HF} / \mathrm{HCl}$ destruction of silicates, in order to eliminate the remaining ions able to form complex fluorides upon drying. After rinsing to neutrality, the kerogen concentrate can then be filtered to dryness, recovered and dried at $100^{\circ} \mathrm{C}$ under an inert gas flow. Once dry, it can be weighed in order to control recovery, ground and stored under inert gas for further steps as described below.

Except for very immature sediments which can loose a few percent of their organic carbon by $\mathrm{HCl}$ hydrolysis during the demineralization procedure, these chemical methods do not alter significantly the structure of kerogens, and do not generate newly formed solvent soluble organic material, as tested by Larsen et al. (1989) on a series of coals of varying maturity starting from immature lignites. However as already indicated above, solvent extraction of whole source rocks before acid attacks does not remove the totality of solvent soluble compounds. Indeed trapped extract is released during acid attacks by both destruction of minerals enclosing some extract in micropores and unfolding of kerogen molecules, due to breaking of hydrogen bonds inside the kerogen structure. It is thus necessary to perform a second extraction once the organic matter has been concentrated. Alternatively, the acid attacks may be performed directly on the whole sedimentary rock and a single extraction done afterwards, but it is not a good procedure if the source rock is rich in extractable compounds, these latter preventing a good contact of minerals by the aqueous acid solutions used for attacks.

Once isolated by this procedure, the kerogen concentrate still contains residual minerals that could not be eliminated by the nonoxidant acids selected for attacks, as noted above. The main remaining mineral is pyrite, frequently enclosed inside the organic network of kerogen, as a normal byproduct of bacterial kerogen formation and incorporation in some sediments. However, many of the classical analyses on kerogens can be done even with pyrite contents up to $40 \mathrm{wt} \%$. Several methods were tested for pyrite elimination from kerogen concentrates in view of specific analyses, but efficient procedures have been set up only recently. They will not be described in detail here; the reader can refer for example to the papers of Acholla and Orr (1993) for chemical destruction and of Stankievicz et al. (1994) for density separation. 


\subsubsection{Description of Materials and Procedures}

The successive acid attacks and rinsing procedure is performed in a specially designed cell (Fig. 2) made of a fluorinated translucent polymer (Voltalef) allowing to check the kerogen vs. liquid level during filtrations. The cell is placed into a heating block permanently adjusting a preset temperature of cell liquids. Its upper part comprises two threaded holes, one open for introduction of initial rock and liquid solutions and escape of inert gas excess, the second connected to a distribution ramp with controlled nitrogen flow and ending by a pipe bubbling into the liquid to insure both mixing and an inert atmosphere. The bottom of the cell is threaded for opening and maintains a grid supporting millipore Teflon filters between Teflon gaskets. The solutions can be pumped through the filters by a flexible tube regulated by a cock and connected to a peristaltic pump. All connecting parts in contact with acid solutions are of course made of $\mathrm{HF}$ and $\mathrm{HCl}$ resistant materials.

The weighed finely ground rock is first placed into a glass beaker, and a preliminary $6 \mathrm{~N} \mathrm{HCl}$ attack is performed at room temperature outside the preparation cell, in order to control a possible abundant foam formation if the initial carbonate content is high. In this latter case, foam is decreased by addition of a few drops of acetone. The ground rock

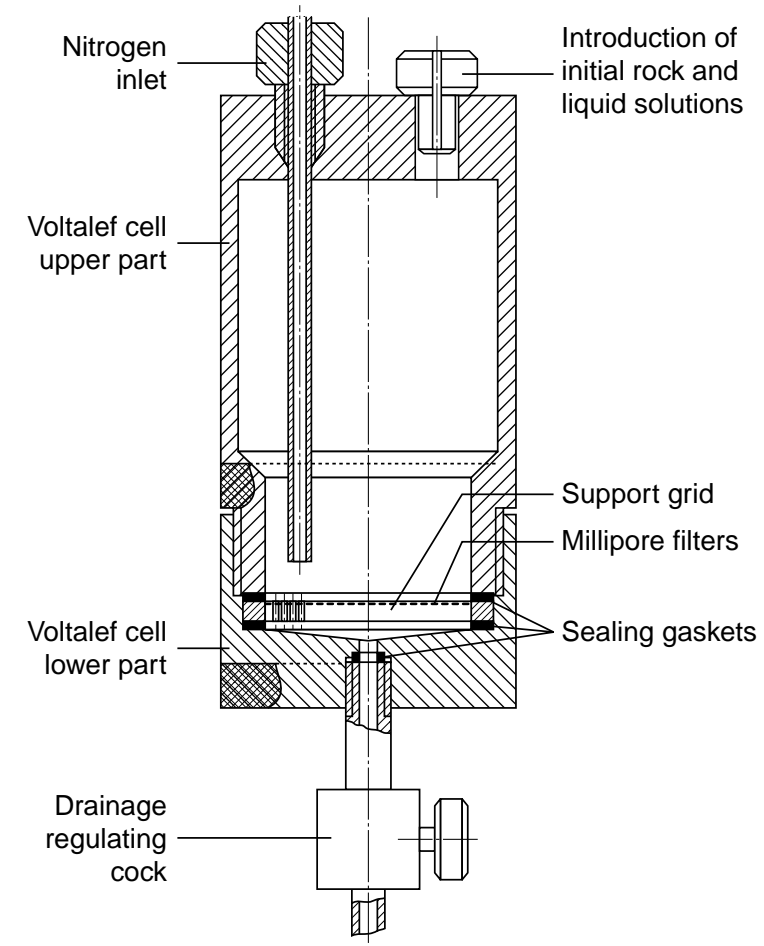

Figure 2

Schematic cross section of a cell designed at IFP for kerogen preparation ("kerogenatron"). suspension is then introduced via a funnel into the cell, the initial acid solution is drained and fresh $6 \mathrm{~N} \mathrm{HCl}$ is added. Heating and nitrogen bubbling are then applied and the succession of attacks and rinsing is performed as described previously. At the end of the whole preparation procedure, the cell is removed form the oven, its bottom is unscrewed and the walls are rinced with deionized water over a small crystallizer to recover the kerogen. The same is done with the Teflon gaskets and the filters with the kerogen. When all kerogen is recovered, the crystallizer is placed into a heating dessicator at $100^{\circ} \mathrm{C}$ under a nitrogen flow to complete drying. The dry kerogen is then crushed in an agate mortar. As isolated kerogen is very prone to oxidation, it is very important to store it under nitrogen atmosphere into a tightly sealed glass container in the dark, and to repeat this storage procedure each time an aliquot of kerogen is sampled for analyses.

\section{USUAL ANALYSES ON KEROGEN}

\subsection{Elemental Analysis}

The major elements in kerogen concentrates are the following: $\mathrm{C}, \mathrm{H}, \mathrm{N}, \mathrm{O}, \mathrm{S}$, and possibly Fe from pyrite, with generally $\mathrm{C}$ and $\mathrm{N}$ amounting respectively for the highest and the lowest weight \%. Elemental analysis is considered reliable if the sum of these elements accounts for more than $90 \mathrm{wt} \%$, but Durand and Monin (1980) cite an average balance of $95 \%$ on 427 kerogen analyses. Given this incomplete mass balance and an average oxygen value of $11 \%$ on 324 kerogen analyses, it is very important that oxygen be measured directly and not calculated by difference. This constraint was already pointed out by coal scientists in the 50s, and a review of methods for direct determination of oxygen, and their comparison with oxygen obtained by difference on a series of reference coals, can be found in Ehmann et al. (1986).

The IFP geochemistry laboratory being not equipped with the various microanalysis apparatus needed for a correct determination of these elements in kerogens, it was decided from the beginning of our studies to carry out these analyses through a specialized laboratory, the same for now more than thirty years. $\mathrm{C}, \mathrm{H}$ and $\mathrm{N}$ are determined on one aliquot of the kerogen by thermal conductivity detection of gases produced from combustion at $1000^{\circ} \mathrm{C}$. Oxygen is measured on another aliquot by pyrolysing the kerogen under nitrogen flow, transforming oxygen-containing gases to $\mathrm{CO}$, then oxidizing $\mathrm{CO}$ to $\mathrm{CO}_{2}$, followed by quantification of $\mathrm{CO}_{2}$ by coulometry. Total $\mathrm{S}$ including pyritic and organic $\mathrm{S}$ is obtained by oxidation of a third aliquot of kerogen followed by quantitative coulometry of $\mathrm{SO}_{2}$. The determination of $\mathrm{Fe}$ is necessary to calculate the amount of pyrite $\mathrm{FeS}_{2}$ in the sample; the organic sulfur may then be calculated by 
difference of pyritic sulfur with the measured total sulfur. This analysis is done on a fourth aliquot by mineralization of the sample by a mixture of nitric and sulfuric acids, then quantification of $\mathrm{Fe}$ by atomic absorption. Other minerals resisting acid attacks, such as barite, rutile and anatase, may be estimated by the difference to $100 \%$ of the sum of previously mentioned elements. Ashes after combustion may also be weighed in order to approximately crosscheck the obtained data. However if pyrite is present, this crosscheck should account for the oxidation of pyrite during combustion.

These analyses are used for classifying the kerogens in a van Krevelen diagram that will be detailed below. This diagram plots the main elements, $\mathrm{C}, \mathrm{H}$ and $\mathrm{O}$ as atomic ratios of $\mathrm{H} / \mathrm{C} v s$. O/C. Starting from the $\mathrm{wt} \%$ analyses, these atomic ratios are obtained by multiplying the weight ratio of $\mathrm{H}$ to $\mathrm{C}$ by 12 , and the weight ratio of $\mathrm{O} / \mathrm{C}$ by 0.75 (i.e. 12/16). If other atomic ratios are needed, the same type of calculation is done, multiplying the weight ratio by the reverse atomic weight ratio of the elements considered; for example the atomic N/C ratio is their weight ratio multiplied by $12 / 14$.

\subsection{Pyrolysis}

\subsubsection{Basic Principles of Pyrolysis Applied to Kerogen Characterization}

Pyrolysis is a widely used degradation technique that allows breaking a complex substance into fragments, by heating it under an inert gas atmosphere. The small compounds thus obtained are building blocks of the complex substance, but they can often be analyzed more easily, eventually up to a molecular level, and quantified. Applying this technique to hydrocarbon generation from kerogen thermal cracking also means that geological conditions with long time intervals at low temperature can be replaced by laboratory conditions with short experiment duration at high temperature, of course in a defined domain where cracking reactions are similar. Accordingly, pyrolysis has become immediately after the development of the kerogen isolation procedure a major technique for geochemical studies on kerogen, both for characterization of its molecular building blocks and for kinetic studies considered later in this paper.

Several types of pyrolysis systems can be used for performing kerogen cracking. Open systems, where effluents are quickly swept away from the hot zone by an inert gas flow or by vacuum extraction, are the easiest for monitoring the formation of molecular building blocks from kerogen, since secondary reactions between generated products should not occur. The operating conditions of such systems are however very far from geological conditions as no pressure can be applied to the kerogen, and pyrolysis occurs simultaneously with thermal extraction, usually with a programmed temperature ramp from 300 to $650^{\circ} \mathrm{C}$. The high final temperature precludes operating on a whole rock, because of catalytic artefacts by dehydrated minerals (Espitalié et al., 1984). Qualitative analytical pyrolysis can be performed by coupling the pyrolysis chamber to a GC column, maintained at low temperature during the pyrolysis step to trap effluents on the column head, then transporting them selectively by the usual temperature program. However quantification is possible only for products carried through the GC column to the detector. It can be seen, by comparing GC quantification with the weight of pyrolysate fractions recovered directly in a cold trap, that recovery depends both on the molecular weight and the chemical structure of products, as shown in Table 1 . Total effluent production is correctly quantified only if products are collected at the output of the pyrolysis oven, either as chemical fractions if the pyrolyzate is first recovered into a cold trap, or as carbon weight if analyzed continuously with a flame ionization detector. Two of these systems conceived at IFP are successively detailed below.

TABLE 1

Comparison of hydrocarbon amounts measured by pyrolysis-gas chromatography (Py-GC) and preparative pyrolysis in $\mathrm{C}_{6}-\mathrm{C}_{13}$ and $\mathrm{C}_{14+}$ carbon ranges, for a maturity series of type II kerogens. Consistency of results for $\mathrm{C}_{6}-\mathrm{C}_{13}$ hydrocarbons and their difference for $\mathrm{C}_{14+}$ hydrocarbons shows that in the latter, a part of hydrocarbons (mainly aromatics from analyses) does not pass through the chromatographic column. Higher quantities measured by Py-GC for the most mature kerogen are due to loss of very light hydrocarbons upon preparative pyrolysis work up (argon evaporation)

\begin{tabular}{c|c|c|c|c|c|c|c}
\hline \multicolumn{4}{c|}{ Type II kerogen series parameters } & \multicolumn{2}{c|}{$\mathbf{C}_{\mathbf{6}}-\mathbf{C}_{\mathbf{1 3}}$ pyrolysate } & \multicolumn{2}{c}{$\mathbf{C}_{\mathbf{1 4}+}$ pyrolysate $^{* *}$} \\
\hline at. H/C & at. O/C & $\begin{array}{c}\text { HI } \\
(\mathrm{mg} / \mathrm{g} \text { C) }\end{array}$ & $\begin{array}{c}\boldsymbol{T}_{\text {max }} \\
\left({ }^{\circ} \mathrm{C}\right)\end{array}$ & $\begin{array}{c}\text { Py-GC } \\
(\mathrm{wt} \%)^{*}\end{array}$ & $\begin{array}{c}\text { Prepar. Py } \\
(\mathrm{wt} \%)^{*}\end{array}$ & $\begin{array}{c}\text { Py-GC } \\
(\mathrm{wt} \%)^{*}\end{array}$ & $\begin{array}{c}\text { Prepar. Py } \\
(\mathrm{wt} \%)^{*}\end{array}$ \\
\hline 1.24 & 0.114 & 661 & 423 & 5.68 & 4.58 & 9.76 & 12.04 \\
1.29 & 0.101 & 680 & 426 & 4.32 & 4.35 & 7.38 & 13.35 \\
1.28 & 0.084 & 730 & 435 & 5.84 & 5.48 & 10.86 & 16.93 \\
1.07 & 0.056 & 590 & 442 & 5.40 & 5.38 & 7.64 & 15.33 \\
0.86 & 0.057 & 260 & 446 & 3.37 & 3.49 & 3.86 & 7.90 \\
0.6 & 0.070 & 36 & 456 & 1.02 & 0.63 & 0.82 & 0.50 \\
\hline
\end{tabular}

* weight $\%$ of the pyrolysed kerogen.

** sum of saturates, unsaturates and aromatics only. 


\subsubsection{Preparative Pyrolysis System for Q uantification of Kerogen Structural Components}

The preparative pyrolysis device (Fig. 3) is a cylindrical minifurnace with gold coated inner wall, as described in previous publications (Béhar and Pelet, 1985; Vandenbroucke et al., 1988). A weighed kerogen amount loaded on a gold rod is introduced into the pyrolysis chamber under argon flow. After preliminary heating at $300^{\circ} \mathrm{C}$ for $3 \mathrm{~min}$ to flush any remaining solvent or water, the temperature is raised to $600^{\circ} \mathrm{C}$ using a temperature program similar to that of classical Rock-Eval pyrolysis. Effluents are swept away and condensed, together with the carrier gas, in a glass trap cooled by liquid nitrogen. After pyrolysis completion, the trap is disconnected and open to let argon evaporate, then the pyrolysate is recovered by addition of solvent at room temperature in the trap, resulting in loss of $\mathrm{C}_{1}-\mathrm{C}_{5}$ products and nonhydrocarbon gases, that can be analyzed separately using a specific pyrolysis device connected to a vacuum line (Lorant and Béhar, 2002). Two preparative pyrolysis experiments are performed for each kerogen sample, one for pyrolysate recovery with $n$-pentane and analysis of the $\mathrm{C}_{6+}$ fraction (Lafargue and Béhar, 1989), the other for pyrolysate recovery with dichloromethane (DCM) and analysis of the $\mathrm{C}_{15+}$ fraction (Béhar et al., 1989).

Fractionation and Molecular Analysis of the Pentane Solution by GC Quantification

The pentane solution is fractionated by microcolumn liquid chromatography on silica into total $\mathrm{C}_{6+}$ saturates (pentane elution) and $\mathrm{C}_{6}-\mathrm{C}_{14}$ aromatics (elution by a mixture pentane/dichloromethane $90 / 10 \mathrm{v} / \mathrm{v}$ ), then quantified by GC/FID (flame ionisation detector). Other products dissolved into pentane are not eluted using these solvent mixtures. However the quantification of the $\mathrm{C}_{6}-\mathrm{C}_{14}$ fraction may be hampered by a partial evaporation of $\mathrm{C}_{6}-\mathrm{C}_{9}$ compounds during preparation. Two standards are used for calibrating the FID. The detector response is linear in the range 0.06 to $1.29 \mu \mathrm{g} / \mu \mathrm{l}$ and is controlled regularly. This response coefficient is used for the quantification of total amounts of $\mathrm{C}_{6+}$ saturates plus unsaturates and $\mathrm{C}_{6}-\mathrm{C}_{14}$ aromatics, by difference of $\mathrm{GC}$ areas of fractions and blanks.

Molecular analysis of the $\mathrm{C}_{6+} n$-alkanes and alkenes is performed by GC-FID. The $\mathrm{C}_{6}-\mathrm{C}_{14}$ aromatics are identified by GC-MS (mass spectroscopy) analysis and their relative amount is quantified both on the total ionic current (TIC) trace and the FID trace with the same response factor as for saturates. These two quantifications give fairly similar results in this carbon range because the aromatic fraction contains mainly mono- and di- alkylaromatics plus alkylthiophenes, with a FID response close to that of saturates; however benzothiophenes have a significantly lower response factor and should be corrected.

\section{Fractionation and Molecular Analysis of the $C_{15+}$ Compounds}

The DCM solution is evaporated and the recovered pyrolysate weighed. It is then partly redissolved into pentane and separated by microcolumn liquid chromatography on

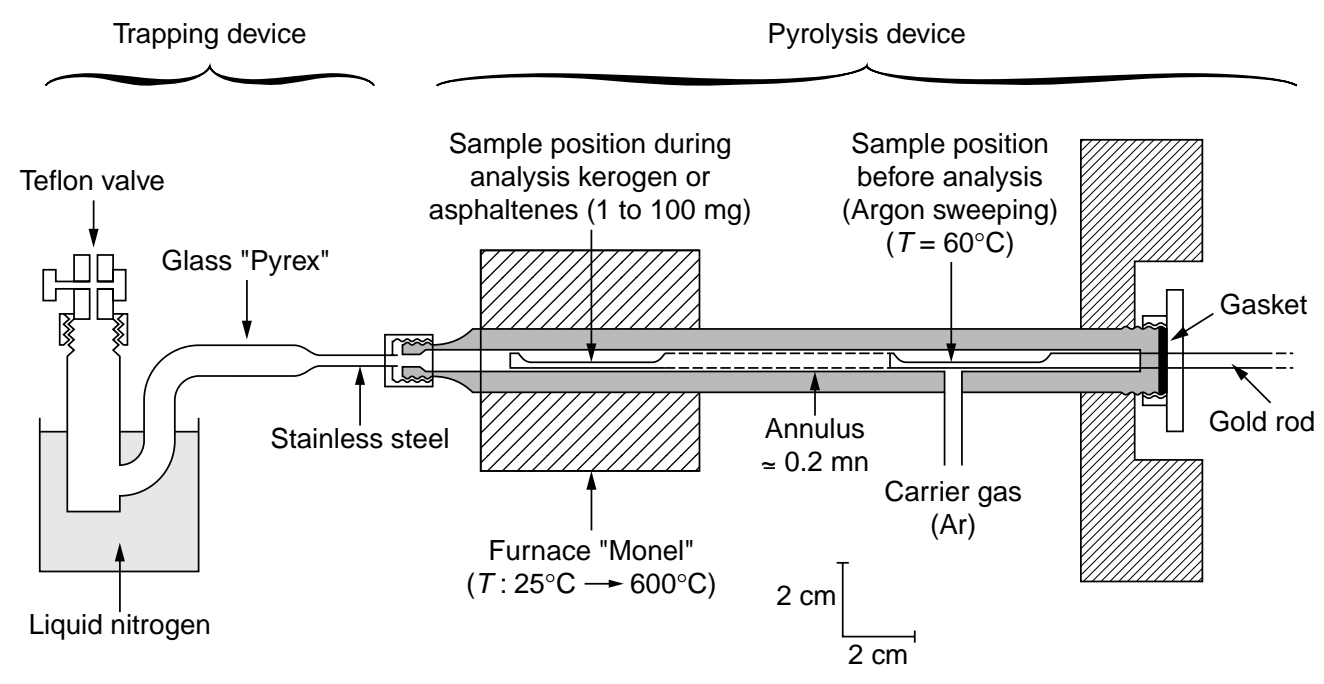

Pyrolysis and trapping device

Figure 3

Preparative pyrolysis device designed at IFP. This device, also named " $\mathrm{S}_{2}$ analyser", has a temperature programmable oven, allowing pyrolysis of a sample under Rock-Eval conditions, and quantitative recovery and analysis of pyrolysis effluents in the $\mathrm{S}_{2}$ peak. 
silica into saturates plus unsaturates (pentane elution), aromatics (pentane/dichloromethane elution, 65/35 v/v) and $\mathrm{N}, \mathrm{S}$ and $\mathrm{O}$ containing compounds (NSO) (acetone elution plus pentane insolubles). After solvent evaporation, the three fractions are weighed. Mass spectrometric group type analysis of the $\mathrm{C}_{15+}$ saturates and aromatics may be performed on these fractions after their mild catalytic hydrogenation $\left(5 \%\right.$ rhodium on alumina, $120^{\circ} \mathrm{C}, \mathrm{pH}_{2}$ 40 bar). NSOs are submitted to elemental analysis.

\subsubsection{The First Rock-Eval Pyrolysis Device}

It is not necessary to present once more the Rock-Eval technique and its worldwide impact on the introduction of organic geochemistry in petroleum companies. This section will thus only focus on the principal studies at the origin of the conception of this revolutionary commercial apparatus, capable of characterizing source rock type, evolution stage and present and remaining hydrocarbon potential, by an analysis lasting less than half an hour. It must be recalled that before Rock-Eval analysis, geochemical studies were performed on a limited number of oils and rock extracts which had to be prepared, fractionated and analyzed by various physicochemical techniques to obtain molecular parameters allowing classification and correlation studies. The same was true for kerogen preparation and analysis, thus the whole geochemical analysis on a sample lasted several days and was quite expensive.

Early attempts to characterize source rock properties such as origin and stage of evolution of organic matter by pyrolysis were those of Bordenave et al. (1970) and Giraud (1970). Isothermal pyrolyses were performed on the crushed rock at $280^{\circ} \mathrm{C}$ during 10 to $30 \mathrm{~min}$ and the effluent trapped in liquid air, then was flushed by helium into a chromatographic column, with analysis of the $\mathrm{C}_{1}-\mathrm{C}_{11}$ fraction. They observed that continental source rocks produced mainly aromatic hydrocarbons whereas marine source rocks produced more paraffins than aromatics. Kerogen evolution stage was determined by pyrolysis of the whole source rock at $500^{\circ} \mathrm{C}$, oxidation of the effluent in $\mathrm{CO}_{2}$, with quantification by gas chromatography. The evolution stage was the ratio of this carbon pyrolysable to $\mathrm{CO}_{2}$ to the total carbon; it was recognized to depend on the origin of the source rock, but much more on its geological evolution stage. Another pyrolysis technique where the oven containing the source rock was directly connected to a flame ionization detector (Leplat and Noël, 1972) was shown to produce pyrograms, the shape of which was characteristic of marine kerogens $v s$. coals. Their maturity was later estimated by connecting the oven to a short chromatographic column used as a cold trap during pyrolysis at $500^{\circ} \mathrm{C}$, followed by $\mathrm{GC}$ analysis of generated $\mathrm{CO}_{2}$ and $\mathrm{C}_{2} \mathrm{H}_{4}$ using a thermal conductivity detector (Leplat and Noël, 1974).
Many studies were also performed at IFP on pyrolysis effluent analysis and its comparison to natural equivalents. A precursor of the preparative pyrolysis system described above was constructed, with programmed heating of kerogen up to $500^{\circ} \mathrm{C}$ under helium flow, and subsequent trapping of effluents in a chloroform bath at minus $5^{\circ} \mathrm{C}$. The pyrolysates of many reference source rocks, recovered after chloroform evaporation, could then be analyzed by the same methods as used for extracts, and the evolution of kerogen residues compared to that in natural series (Vandenbroucke et al., 1977; Huc, 1978; Monin et al., 1980). Thermogravimetry and pyrolysis effluent analysis by mass spectrometry was also a major research topic at this time. Many analyses were performed on generation of $\mathrm{H}_{2} \mathrm{O}, \mathrm{CO}_{2}, \mathrm{SO}_{2}, \mathrm{H}_{2} \mathrm{~S}, \mathrm{CH}_{4}$ and hydrocarbons by kerogens, associated with their source rock or isolated from minerals (Souron et al., 1974; Souron et al., 1977; Durand-Souron et al., 1982). The studied samples were heated under vacuum in the source of a mass spectrometer, programming the temperature up to $500^{\circ} \mathrm{C}$ at $5^{\circ} \mathrm{C}$ per minute. Comparison of gases produced in presence or absence of minerals showed that $\mathrm{CO}_{2}$ issued from the organic matter should not be analyzed above $390^{\circ} \mathrm{C}$ because some mineral carbonates, and particularly siderite, could decompose beyond this limit.

This series of studies on kerogen pyrolysis products enabled the conception and production of a first commercial apparatus, the Rock-Eval 1 (Espitalié et al., 1977a; Espitalié et al., 1977b). This first generation Rock-Eval apparatus was an open pyrolysis system, with inert gas flow extracting the effluents generated during programmed heating of the weighed whole rock placed in a porous crucible. Heating to $300^{\circ} \mathrm{C}$ resulted in a thermovaporization of hydrocarbons already present as such in the rock $\left(\mathrm{S}_{1}\right.$ peak), whereas hydrocarbons produced in the $300-550^{\circ} \mathrm{C}$ temperature range resulted from kerogen cracking $\left(\mathrm{S}_{2}\right.$ peak). This latter peak becoming smaller and produced later with increasing natural evolution, the pyrolysis temperature for which the peak was at its maximum was used as a maturity parameter. As a result of mass spectrometric studies, $\mathrm{CO}_{2}$ from kerogen cracking was analyzed only for temperatures under $390^{\circ} \mathrm{C}$. Products carried out of the heated rock by the gas were directed through a splitter with flow regulating valves, either to a flame ionization detector for on-line quantitative analysis of hydrocarbons, or to a trap with molecular sieves connected to a Porapack column and a thermal conductivity detector. At the end of the pyrolysis, the trap was heated to release $\mathrm{CO}_{2}$ which was then quantified ( $\mathrm{S}_{3}$ peak). The main parts and operational flowsheet of this apparatus are shown on Figure 4.

Rock-Eval pyrolysis determines kerogen properties inside source rocks, without need to isolate it from minerals. Although the initial objective of Rock-Eval pyrolysis was the screening of source rocks in exploration wells, the method has been used for many other studies, including its almost 


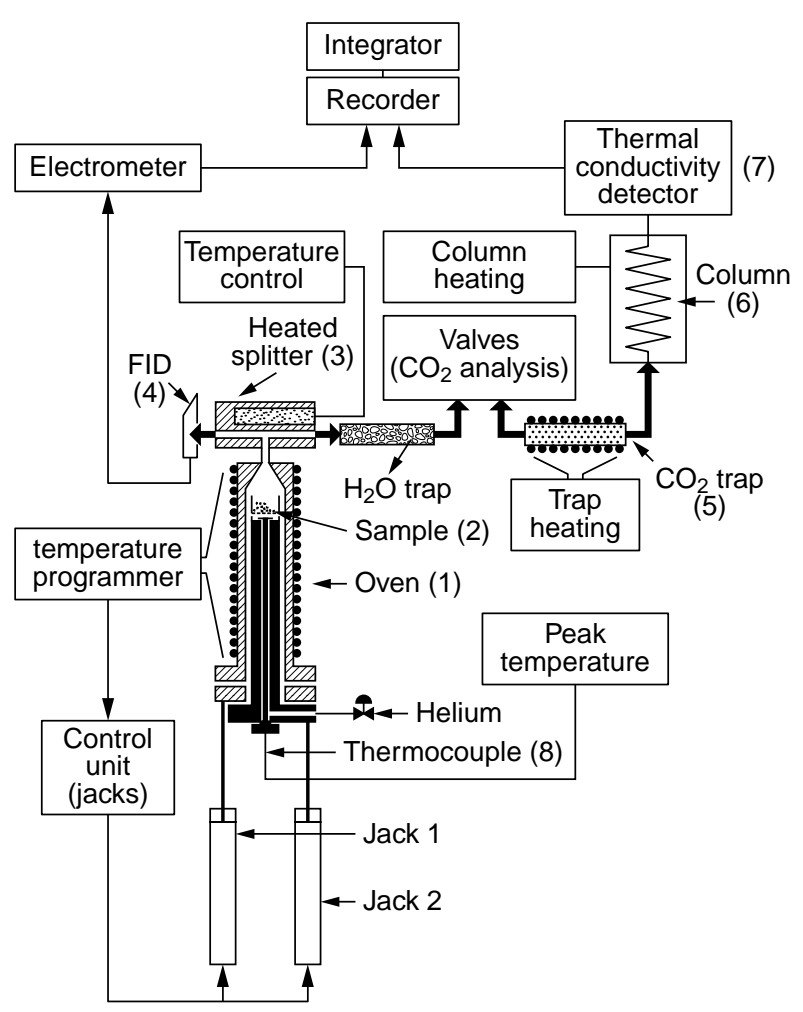

Figure 4

Schematic cross section of the first commercial Rock-Eval (from Espitalié et al., 1977).

systematic application to kerogen analysis in IFP, resulting in useful complementary analytical data. Several versions of the Rock-Eval apparatus have been constructed since the time of its first industrial production. The latest version, Rock-Eval 6, has several new functionalities associated with major technical modifications (Lafargue et al., 1998; Béhar et al., 2001), allowing much more robust and informative parameters to be obtained.

\subsection{Solid State ${ }^{13} \mathrm{C}$ N MR}

Adaptation of ${ }^{13} \mathrm{C}$ NMR to solid samples at the beginning of the 80 s has shown a great potential for quantitative analysis of kerogen functionalities. Indeed it is the only method that can give, under controlled experimental conditions, quantitative estimates of the different carbon bond types in kerogens, as opposed to infrared spectroscopy where only qualitative comparisons are possible. Without entering into instrumental details, removal of dipolar interactions in the solid by magic angle spinning (MAS), and cross polarisation

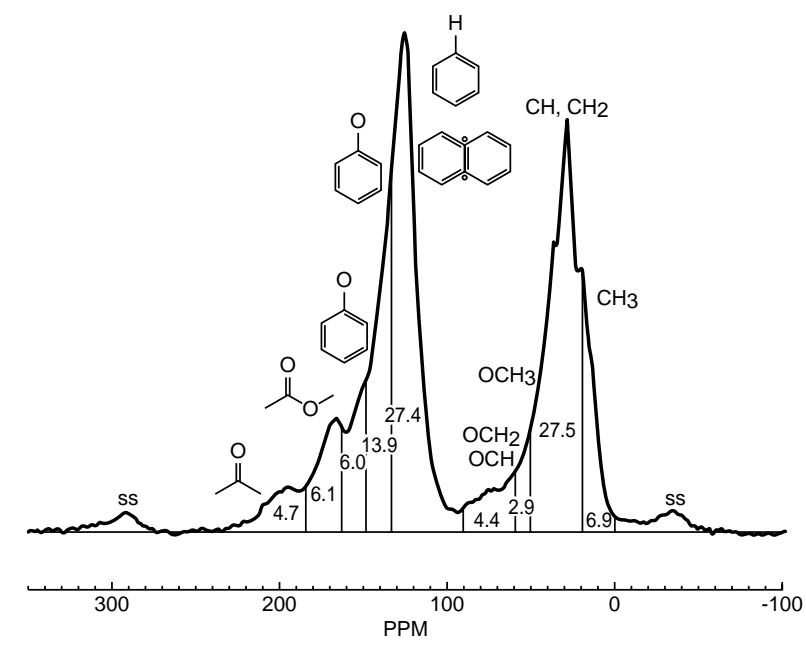

Figure 5

Example of a lignite spectrum obtained with solid state ${ }^{13} \mathrm{C}$ RMN (aromaticity factor 0.58 ), and identification and quantification of peaks in wt\% of total carbon. ss (spinning sidebands) peaks do not belong to the coal sample.

(CP) between carbons and protons using appropriate contact times (around $1 \mathrm{~ms}$ ), enable a fairly quantitative response with good resolution of all carbon types in kerogen to be obtained (Maciel et al., 1979; Hatcher, 1980). Given the low amount of ${ }^{13} \mathrm{C}$ in total carbon, a large number of spectra need to be accumulated to enhance the signal to noise ratio. It is then possible to integrate separately peak areas corresponding to given carbon environments and express them as $\mathrm{wt} \%$ of the total carbon.

An example of a ${ }^{13} \mathrm{C}$ CP/MAS spectrum of a coal sample and the related functional quantification is shown on Figure 5. Major oxygen containing functional groups can be analyzed with this technique, beside aliphatic and aromatic structures. However heteroelements inside aromatic rings cannot generally be seen in coals and kerogens. Peaks in spectra of kerogens and coals are fairly broad due to the large number of different carbon environments for a given bond type. The uncertainty of the quantification is estimated to be around $10 \%$.

\section{CASE STUDIES ON REFEREN CE PETRO LEUM SYSTEMS}

\subsection{History of Geochemical Studies Performed at IFP During the Period 1965-1975}

A large number of geochemical studies on petroleum systems, in collaboration with oil companies or state 
geological institutions, was performed at IFP during this period. These studies, providing a large number of natural samples of oils and source rocks from reference basins for geochemical analyses, were at the basis of major geochemical observations and concepts. In the course of these studies, detailed below, it was possible:

- to set up and apply an analytical procedure for both extraction and analysis of source rocks, and distillation and oil analysis, enabling oil-oil and oil source rock correlation (Oudin, 1970; Durand and Espitalié, 1970; Durand et al., 1970);

- to validate on geological examples the kinetic models of kerogen transformation into petroleum;

- to prepare and analyse a large number of kerogens, leading to their classification according to organic source and thermal evolution.

In parallel, collaborations on more fundamental research subjects, often in the form of financial support of doctoral studies, were initiated with several universities, particularly Louvain and Strasbourg, and research institutes, such as the Cerchar.

\subsection{Reference Petroleum Systems Analyzed at IFP During the Period 1965-1975}

\subsubsection{The Toarcian Marls (Paper Shales) from the Paris Basin (France)}

Many geochemical analyses of the kerogen and extractible organic matter of this reference source rock series from the lower Toarcian paper shales were performed in IFP during this time (Louis, 1966; Louis and Tissot, 1967; Oudin and Califet-Debyser, 1969; Durand and Espitalié, 1971; Tissot et al., 1971; Durand et al., 1972; Espitalié et al., 1973), and there are still ongoing analyses in IFP and elsewhere. Many wells were drilled during petroleum exploration in this basin, resulting in a large number of cored samples at different burial depths, from outcrops in the east of France to a maximum depth around $2500 \mathrm{~m}$. Samples and related informations were kindly provided by Erap, Mobilrex, SNPA and Petrorep.

In the Paris Basin, this series with an age of $180 \mathrm{Ma}$ and a thickness ranging from 10 to $20 \mathrm{~m}$, rich in organic matter, was deposited in a homogeneous environment under $100 \mathrm{~m}$ water, and further basin subsidence resulted in transformation of kerogen into petroleum, allowing availability of a particularly homogeneous maturity suite. This series was also one of the first examples on which a kinetic simulation of the petroleum generation using the cracking scheme of Tissot (1969) was performed (Deroo et al., 1969), and also one of the first where kerogens were prepared, analyzed and placed into a van Krevelen diagram to show the kerogen evolution path (Durand et al., 1972), as described in a later section (Part 3.4).

\subsubsection{The Devonian and Silurian Hot Shales from the Illizi Basin (Algeria)}

This petroleum system contains very old and rich source rocks, mainly of lower Silurian and upper Devonian age, with local source rocks in the Ordovician and upper Silurian formations (Tissot et al., 1974). Oils and source rock samples were provided by $E l f-R E$. All oils are very light, with a predominance of alkanes containing less than 15 carbons and a very low NSO content. Distinguishing criteria between oils could be found only on the basis of structural group analysis of aromatic fractions, separating oils coming from a local upper Silurian source rock from undistinguishable oils sourced by lower Silurian and upper Devonian source rocks.

The structural history of this ancient basin is complex and comprises two main subsidence periods separated by a major uplift and erosion during the Hercynian orogenesis. Modelling of oil and gas formation in this petroleum system was performed using a modified cracking scheme accounting for gas (Tissot et al., 1974), on the basis of the burial history of source rocks and the timing of trap formation. The model was able to explain the absence of oil in the SW part of the basin, the presence of gas in NE (Alrar, In Amenas), condensates in SE (Zarzaïtine) and oil and gas in NW (Tin Fouyé Tabankort), this latter gas coming from a major contribution of the lower Silurian source rock.

\subsubsection{The Devonian Shales from the Alberta Basin (W estern Canada)}

The geochemical study of this petroleum system, a joint project with the Geological Survey of Canada (Deroo et al., 1977; Deroo and Powell, 1978), was performed on a large number of conventional oils (106), heavy oil extracts (63) and sediment extracts (189). Two areas of the Alberta syncline were studied: a deep central zone, and the so called "heavy oil belt" including the Athabasca tar sands.

This petroleum system study brought new insights into source rock variability, geochemical tools for oil/source rock correlation, migration distances and influence of biodegradation on geochemical parameters. Three source rock intervals were present in this basin:

- the Mannville shales (lower Cretaceous), associated with coals, were the first example of organic matter sourced by land plants, and many kerogens were prepared and analysed;

- the marine limestones of middle and upper Devonian;

- the marine shales of upper Cretaceous.

Differentiation of oil families was only possible through a systematic analysis of aromatic hydrocarbons, both by gas chromatography with a sulfur specific detector and by group type analysis with low voltage mass spectrometry. Long migration distances, possibly higher than one hundred kilometers, were deduced from correlations of oils and adequately mature source rocks, on the basis of geology and 
maximum burial depth. These unusually long distances were possible through a major regional unconformity acting as a route for fluids. Finally the study of water salinity associated to more or less heavy oils showed that biodegradation, and possibly water washing, occurred by infiltration, through reservoir outcrops, of fresh water bringing bacteria. The biodegradation level could be correlated to observed changes in molecular and compositional geochemical parameters, such as the disappearance of $n$-, then iso-alkanes, then some aromatics, the vanadium and nickel concentration, or the increase of the asphaltene content.

\subsubsection{The Logbaba Silty Clays from the Douala Basin (Cameroon)}

The petroleum system of the Douala basin is located SE of the present Niger river delta, and began to form in conjunction with the opening of the South Atlantic ocean. Upper Cretaceous detrital sediments, alterning sands and silty clays and carrying continental organic matter, were deposited and quickly buried in a shallow marine environment. The mineral and organic homogeneity of these sediments, associated with a significant total thickness allowing a large range of maturities to be studied, made this series particularly interesting. It was the subject of doctoral studies on the mineral (Dunoyer de Segonzac, 1969) and organic (Albrecht, 1969) contents, followed by a collaborative study including kerogens between IFP, Strasbourg University and Elf-RE and its subsidiary Elf-Serepca (Albrecht et al., 1976; Durand and Espitalié, 1976; Vandenbroucke et al., 1976).

The comparison of source and transformation characteristics between the terrestrial organic matter from this petroleum system, and the marine organic matter from Toarcian shales in both the Paris Basin and their higher maturity German equivalents, was a key point in undestanding the chemical differences in petroleum potential and oil composition between these two reference series. The preparation and analysis of a large number of kerogens in both series was also at the basis of the classification of kerogen types and evolution paths in a van Krevelen diagram of $\mathrm{H} / \mathrm{C}$ vs. $\mathrm{O} / \mathrm{C}$ atomic ratios, as detailed in Part 3.4.

\subsubsection{The Green River Shales from the Uinta Basin (USA)}

The Green River shales is an organic-rich formation extending over several states of USA. It was deposited in two Paleocene/Eocene alkaline palaeolakes, lake Gosiute in Wyoming, and lake Uinta in Utah and Colorado. Climatic conditions and alkaline mineral supply favored high productivity and preservation of specific microorganisms, possibly blue-green algae and bacteria resisting such agressive environments. However the exact nature of the organic supply is unknown, because no organic fossils could be identified. The geochemical study of this formation at $I F P$, in collaboration with Shell USA, focused on the Utah part of the Uinta basin, the main question being to clarify the respective influence of source differences and maturity on the origin and composition of crude oils (Tissot et al., 1978).

Unexpected analytical difficulties caused by the highly paraffinic nature of oils and extracts had to be solved first, because $\mathrm{C}_{25+}$ hydrocarbons reprecipitated during compound separation with usual solvents. It appeared then that slight differences associated with changes in depositional environments could be detected at a similar maturity level, based on the composition of specific biomarkers in alkane fractions. Thanks to the large maturity range of the studied samples, it was possible to define on the related kerogen series a new type and evolution path, confirming not only the highly aliphatic nature and the hydrocarbon potential of this organic matter, but also its specific thermal behavior, characterized by a late and very narrow oil window when compared to other source rocks.

\subsubsection{The Clays and Coals from the Mahakam Delta (Indonesia)}

The study of this petroleum system, in collaboration with Total CFP, Total Indonesia, Inpex and Pertamina, was of particular interest due to the nature and homogeneity of its Miocene source rock associating coal beds and dispersed organic matter deposited in a deltaic setting under tropical climate, by the high quality and large maturity range of samples, and by the geological setting of oil and gas fields in a series of parallel structural trends perpendicular to the sediment supply by the Mahakam river. Numerous geochemical studies were performed on oils, source rocks, coals and kerogens, in IFP and CFP labs (Combaz and De Matharel, 1978; Durand and Oudin, 1980; Vandenbroucke et al., 1983; Huc et al., 1986), as doctoral studies (Boudou, 1981), and on corresponding recent sediments by the Misedor group (Pelet, 1987).

Many new insights or confirmations concerning the kerogen analysis and petroleum potential were obtained by geochemical studies on this petroleum system. Among these were:

- confirmation that terrestrial plant sourced kerogens and coals have similar composition and petroleum potential, whereas this was not possible with the Logbaba series where coals were not found;

- characterization of such post Cretaceous "perhydrous" coal series as source rocks for oil, and not only for gas as previously thought;

- observation of very easy migration of oil and gas in deltaic systems due to the close mixing of sand and shale sediments.

These observations thus raised the interest of petroleum companies for Tertiary deltaic systems under tropical climates as new zones for oil and gas exploration, with many commercial successes obtained since that time. 


\subsection{The Development of Kinetic Models of Kerogen Cracking into $\mathrm{O} \mathrm{il}$ and $\mathrm{G}$ as}

Only the main principles of early kinetic models of kerogen transformation into petroleum and the related publications using the reference petroleum system studies presented above will be described briefly here. Other papers in this journal issue, including the translation of the precursor paper of Tissot (1969), will show the applications of such models for oil exploration.

It is indeed impossible, given the variety of the chemical structures and bonds in kerogen, to describe primary cracking by elementary free-radical reactions. The main steps of kerogen cracking in early models were thus similar to those described for thermal conversion of coal, namely depolymerization, tar cracking and residue cokefaction. Depolymerization of kerogen was thus represented by a reaction producing intermediate heavy compounds extracted at this time by a mixture of methanol, acetone and benzene (MAB), together with a condensed residue and gases, both hydrocarbons and nonhydrocarbons. The MAB compounds were in turn transformed into petroleum compounds plus again condensed residue and gases. Already at this time kerogen, being recognized as a chemically complex molecule, was considered to generate MAB compounds by a number of parallel and/or successive pseudo-reactions thought to reflect the various bond energies in a given kerogen. Kerogen, $\mathrm{MAB}$ compounds and petroleum (chloroform extract) being respectively $\mathrm{A}, \mathrm{B}$ and $\mathrm{C}$, the reaction scheme is:

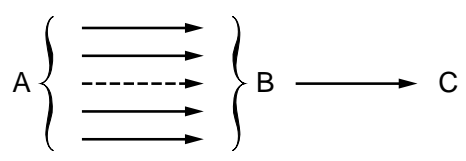

Quantitative data were calibrated in first models on the evolution with depth of extract amounts in reference petroleum systems. Assuming that all reactions are first order and that rate constants follow the Arrhenius law (see translated paper for details of equations), kinetic parameters of this scheme were calibrated on 24 samples from the Paris Basin for which the burial history, and thus the temperature applied to the system was reconstructed (Tissot and Pelet, 1971). This calibration allowed recalculation of the theoretical petroleum generation of the Dogger marls of the Paris Basin (similar to the Toarcian shales) and comparison with the presence or absence of petroleum accumulations in this same formation. The result is shown on Figure 6.

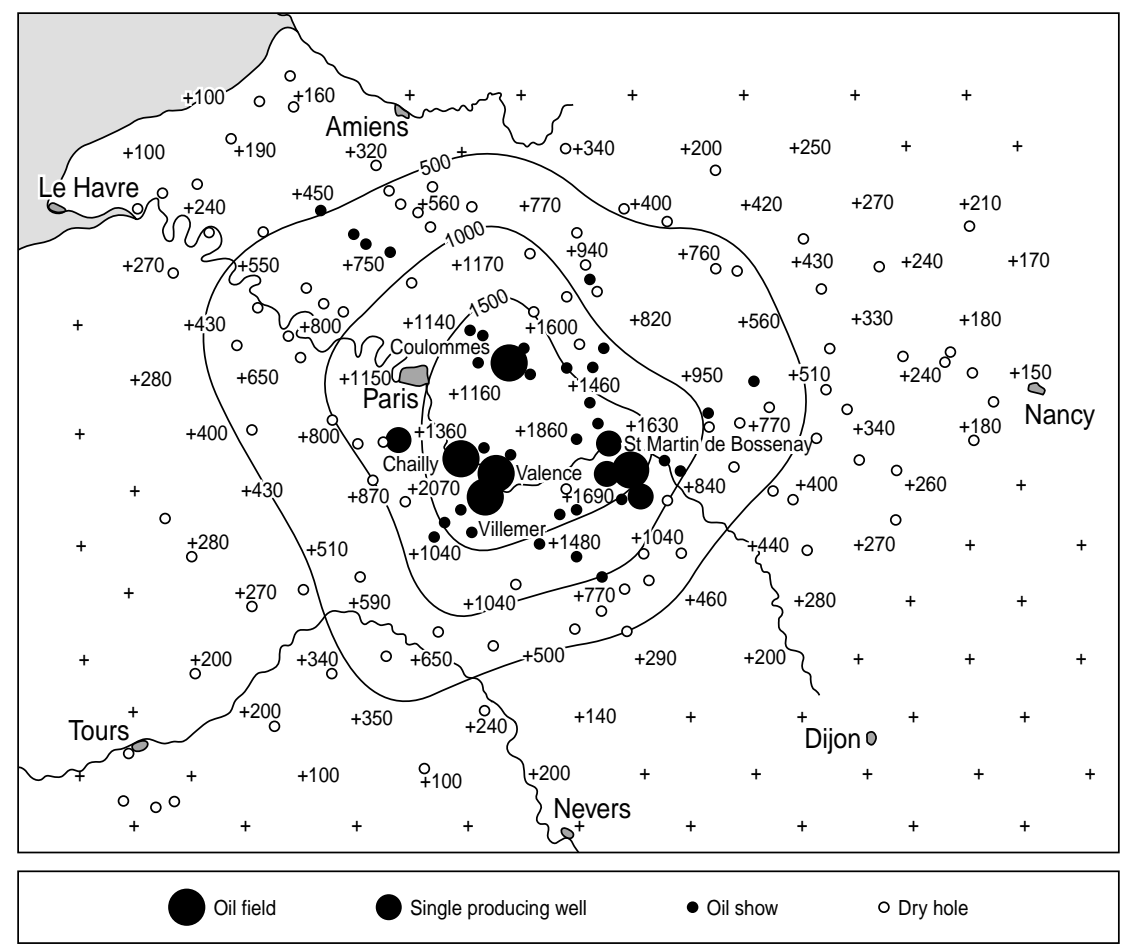

Figure 6

Modeling of oil generation (figures in gram of petroleum per ton of source rock) in the Dogger source rocks of the Paris Basin and position of oil fields, producing wells and dry holes resulting from drilling. The modeled quantities fit closely the observed accumulation zones (from Tissot and Welte, 1978, p. 510; copyright Springer-Verlag). 
A new model accounting for changes in both analytical procedures (MAB extraction was abandoned due to solvent toxicity), and more important, in the classification of kerogen types as described in the next section, was proposed by Tissot and Espitalié (1975). The reaction scheme, with A, B, $\mathrm{C}$ being respectively kerogen, oil and gas, was:

$$
\mathrm{A}\left\{\begin{array}{l}
\vec{\longrightarrow} \underset{\longrightarrow}{\longrightarrow}
\end{array}\right\} \mathrm{B}\left\{\begin{array}{l}
\vec{\longrightarrow} \\
\vec{\longrightarrow}
\end{array}\right\} \mathrm{C}
$$

Calibration of kinetic parameters was performed not only using extract amounts produced at various evolution stages in geological conditions, but also by combining this information with thermogravimetric experiments, i.e. kerogen weight loss on pyrolysis under nitrogen. Six pseudo-reactions were used, with fixed increasing activation energies between 10 and 80 $\mathrm{kcal} / \mathrm{mol}$. Frequency factors of the Arrhenius law and kerogen fractions associated with each pseudo-reaction were calculated by numerical optimisation. The organic matter type was shown to influence the final weight loss of kerogen, as well as its contribution to the various pseudo-reactions. The comparison of oil and gas generation curves obtained with this kinetic model in standard geological conditions for various kerogen types is shown on Figure 7.

Further developments in kinetic models no longer use the data obtained on natural series, and are accordingly out of the scope of this review. It suffices to say that their development increased continuously in close relation with numerical modeling of petroleum systems, and that they are at the source of numerous petroleum discoveries.

\subsection{The Classification of Kerogens from these Case Studies: Notion of Type and Evolution Path}

\subsubsection{Building up the Concepts}

The classification of kerogens from sedimentary source rocks into three main types, and their evolution during maturation in geological conditions following "carbonization paths" were first proposed by Durand et al. (1972), on the basis of elemental analyses of kerogens from the Paris Basin and related literature data on various kerogens from different ages and locations (Mc Iver, 1967). These analyses were represented in an atomic $\mathrm{H} / \mathrm{C} v s$. O/C diagram similar to the one used for coals by van Krevelen in 1950 (van Krevelen, 1961), and were compared with the coalification paths of coal macerals (Fig. 8). Elemental analyses of maturity series of kerogens, obtained progressively from geochemical analyses of petroleum systems described above (except for the Mahakam coals and shales and the Green River shales) were included in this diagram, allowing "evolution paths" to be defined (Durand and Espitalié, 1973; Tissot et al. 1974). The Green River shales (Tissot et al., 1978) were then added to these reference series of kerogens (Fig. 9) by Tissot and Welte (1978). The three types of organic matter defined in
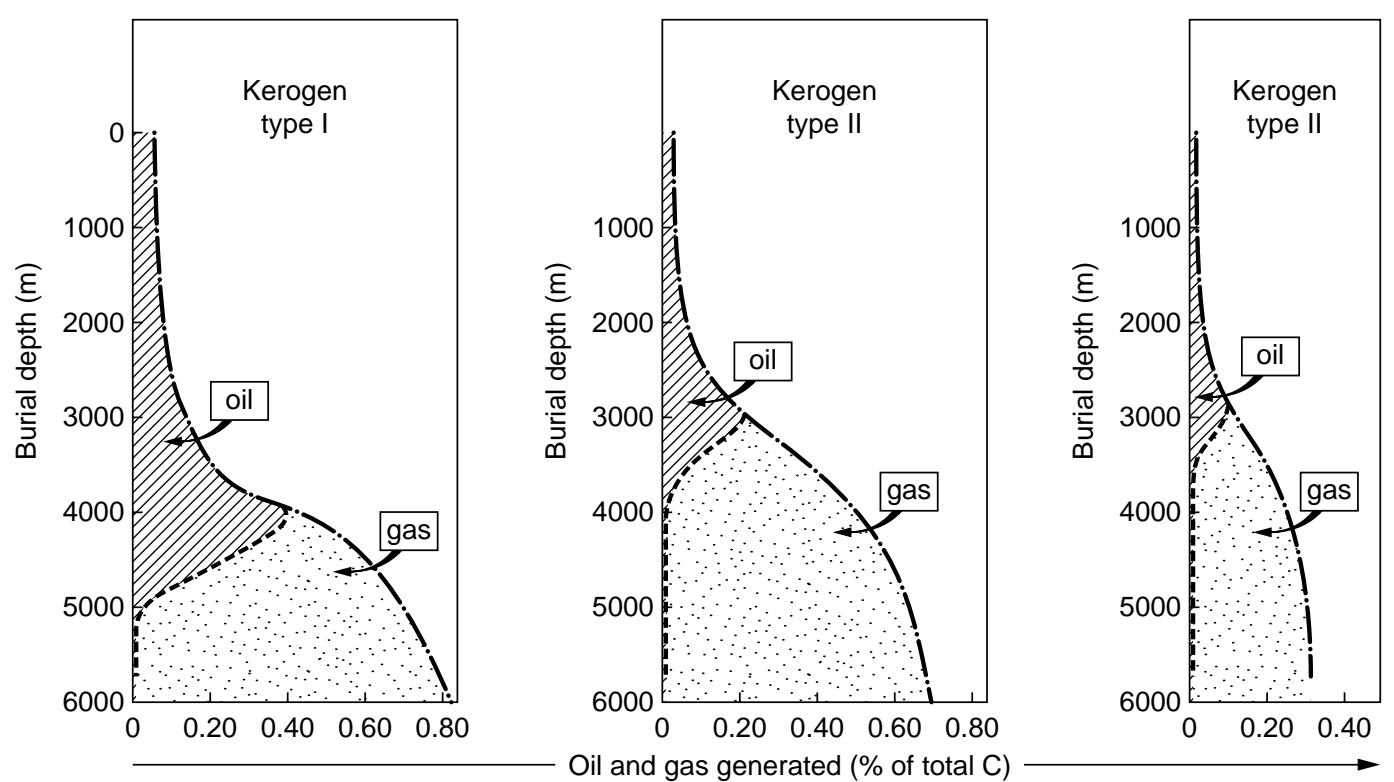

Figure 7

Comparison of oil and gas production from the three kerogen types resulting from the cracking model of Tissot and Espitalié (1975), with a constant burial of $60 \mathrm{~m}$ per Ma and a geothermal gradient of $35^{\circ} \mathrm{C}$ per km (after Tissot and Espitalié, 1975). 


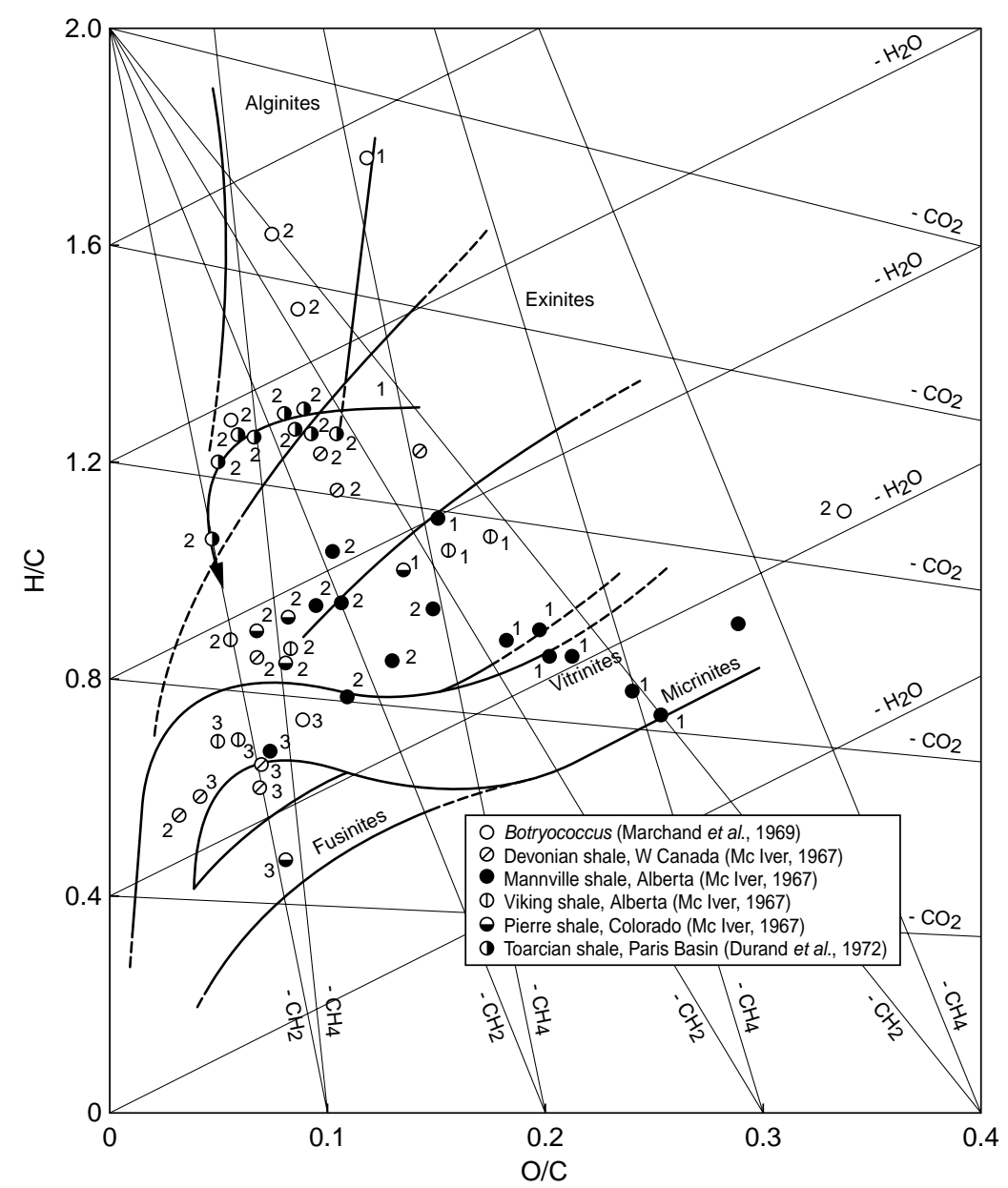

Figure 8

Comparison of elemental analyses from kerogens of the Paris Basin (Durand et al., 1972) and various kerogen series (McIver, 1967) in the diagram of atomic ratios H/C and O/C for coal macerals (van Krevelen, 1961). The numbers 1, 2, 3 correspond respectively to low, medium and high maturity. The "carbonization path" is indicated for the Paris Basin kerogens (after Durand et al., 1972).

this "van Krevelen diagram" were associated by Tissot et al. (1974) with the specific depositional environments of these petroleum systems. Other source rock samples, although available only in a limited range of maturity, were generally shown to fit the position related to the predicted depositional environment in this diagram, except for lacustrine settings as discussed below. Elemental analyses of kerogens, reflecting their chemical structure, can thus be used for characterizing both the type of the organic matter in petroleum source rocks and its evolution with increasing burial in geological conditions.

\subsubsection{Kerogen Types: Chemical Characteristics and Depositional Environment}

The chemical characteristics of kerogens of reference petroleum systems corresponding to the initial definition of types I to III and their associated depositional environment are, in order of decreasing petroleum potential:

- The Green River shales from the Uinta basin of Utah, as the reference type I, although some levels in this source rock formation contain classical coals. Except in these latter levels, the organic matter of immature samples was observed to be very aliphatic, with atomic $\mathrm{H} / \mathrm{C}$ frequently higher than 1.5. The oxygen content is often low, although the atomic $\mathrm{O} / \mathrm{C}$ ratio of immature samples may vary from 0.03 to 0.1 . The analysis of oxygen functional groups in immature kerogen (Fester and Robinson, 1966) shows a major participation of unreactive oxygen assumed to be located in aliphatic ether bonds. In accordance with the high initial $\mathrm{H} / \mathrm{C}$ ratio, the extracts, oils or pyrolysis products are very rich in long chain $n$-alkanes, extending over 40 carbon atoms, without marked odd or even 


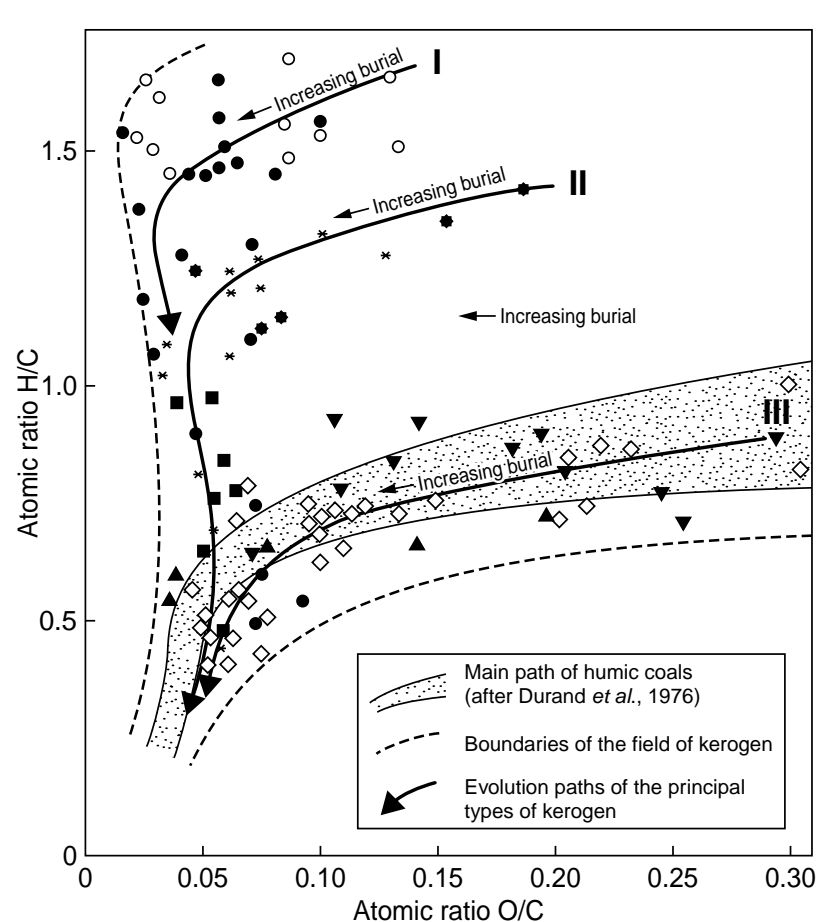

\begin{tabular}{|c|l|l|c|}
\hline Type & \multicolumn{1}{|c|}{ Age and/or formation } & \multicolumn{1}{|c|}{ Basin, country } & \\
\hline \multirow{2}{*}{ I } & Green River shales (Paleocene-Eocene) & Uinta, Utah, USA & $\bullet$ \\
\cline { 2 - 4 } & $\begin{array}{l}\text { Algal kerogens (Botryococcus, etc.), } \\
\text { various oil shales }\end{array}$ & & 0 \\
\hline \multirow{2}{*}{ II } & Lower Toarcian shales & Paris, France, W. Germany & $*$ \\
\cline { 2 - 4 } & Silurian shales & Sahara, Algeria and Libya & $\mathbf{\square}$ \\
\cline { 2 - 4 } & Various oil shales & & $\bullet$ \\
\hline \multirow{2}{*}{ III } & Upper Cretaceous & Douala, Cameroon & $\diamond$ \\
\cline { 2 - 4 } & Lower Mannville shales & Alberta, Canada & $\Delta$ \\
\cline { 2 - 4 } & Lower Mannville shales (Mc Iver, 1967) & Alberta, Canada & $\nabla$ \\
\hline
\end{tabular}

Figure 9

Definition of types and evolution paths of kerogens based on petroleum reference series as indicated (from Tissot and Welte, 1978, p. 143; copyright Springer-Verlag).

predominance. The abundance of iso- and anteiso-alkanes and other biomarkers specific of microorganisms such as carotane led Tissot et al. (1978) to conclude that the initial organic matter input (probably Cyanophycea) had been strongly reworked by bacteria that could have sourced the major part of the finally sedimented organic matter. It is worth noting that the lacustrine environment associated with Green River shales is not freshwater, and that it may contain very unusual alkaline minerals. Other type I kerogens such as Autun boghead (France), torbanite (Scotland) or recent materials such as Coorongite (Australia), principally derived from Botryococcus remains, which also sedimented in a lacustrine setting, although in this case with freshwater, were shown to be located in the same region of the van Krevelen diagram as this Green River series. The kerogen of the organic-rich marine tasmanite from Tasmania was also classified as Type I by Tissot and Welte (1978). As very different sources, only characterized by their common highly aliphatic nature, are classified as type I, it is not really a type because of the different biological precursors, sedimentary environments, preservation conditions implicated in the formation of these kerogens. It should also be noted that source rocks containing these kerogens, although they have a high petroleum potential, are not widespread, and the geographical and geological extension of such organic deposits is generally very restricted. According to Klemme and Ulmishek (1991), they represent only $2.7 \%$ of the world's original reserves in petroleum and gas.

- Type II is based on the lower Toarcian shales of the petroleum system from the Paris Basin (France) and the equivalent Posidonienschiefer (Lias $\varepsilon$ ) formation in Germany. The atomic $\mathrm{H} / \mathrm{C}$ ratio of immature kerogens is about 1.3 and the corresponding $\mathrm{O} / \mathrm{C}$ ratio around 0.15 . As shown by the group type analysis of kerogen pyrolysates and natural extracts (Tissot and Vandenbroucke, 1983), this organic matter contains much more aliphatic cyclic moieties than in type I, and a large amount of aromatics, the structure of which often comprises several aliphatic cycles that convert to aromatic cycles with progressive maturation. The $n$-alkane distribution in extracts or pyrolysates is generally restricted to the carbon range under 25 atoms, even at low maturity. Sulfur is always associated with this type of organic matter, either as pyrite and free sulfur, or in organic structures of kerogen such as aliphatic sulfur and thiophenic rings. The depositional environment associated with these Toarcian shales, as well as to their homologues in Germany, was a moderately deep marine environment with planktonic input as the primary source. Reworking by various bacterial communities occurred to a varying extent, depending on the location of the oxic/anoxic boundary. This Toarcian organic matter type was compared to other source rocks from marine deposits in different regions of the world (for example Devonian of Western Canada, Silurian and Devonian from North Africa). The comparison showed very homogeneous chemical characteristics both for kerogens and for extracts, oils and pyrolysates. Differences in the sulfur content of the organic matter were attributed to the different mineralogical compositions of these source rocks, the richest in carbonates being the richest in organic sulfur, because in that case iron coming from clays is not available for pyrite formation.

- Type III was initially based on the upper Cretaceous sedimentary rocks of the Douala basin (Logbaba, Cameroon), sourced by continental deltaic input and deposited in shallow marine environment (Albrecht et al., 1976). This type of organic matter is frequently found in deltaic settings and derives from higher plant debris, often highly reworked due to the oxidant transportation 
conditions associated with detritic sedimentation. In the case of the Logbaba silty clays, no coal beds were found at any depth. Only the most resistant chemical constituents of the terrestrial organic matter reached the sedimentation region, and once there, they were quickly buried due to the large sediment input and high subsidence rate caused by the opening of South Atlantic Ocean. Under these conditions, strong bacterial degradation probably could not occur as no sulfur was incorporated in the organic matter or as pyrite, even though sulfates were present in the seawater. As seen by both chemical and optical analyses, the organic fraction is for a large part ligneous debris with a predominantly aromatic structure, together with moieties derived from the protective constituents of higher plants with a predominantly aliphatic structure rich in long chain alkanes on the other hand. This latter part of the terrestrial organic matter is probably always a minor fraction of total kerogen. However, this double contribution explains the apparent discrepancy observed between the mostly aromatic kerogen composition as seen by elemental analysis with an atomic $\mathrm{H} / \mathrm{C}$ ratio lower than 0.8 (Durand and Espitalié, 1976), and the highly paraffinic extracts and oils generated by this type III kerogen in comparison with products generated form type II (Vandenbroucke et al., 1976). Other examples of type III organic matter were found also in the lower Mannville shales of Alberta, Canada. It was only with the extensive studies carried out on the organic matter maturity series of the Mahakam delta (Eocene/Miocene) in Indonesia (Combaz and de Matharel, 1978), that it was shown that pure coals and type III shales occurring together in these sedimentary rocks are derived from the same precursors. The detailed geochemical study of kerogens from shales and coals showed that there is no noticeable difference between massive coal and shale evolution at any maturity stage, although humins from very immature coals and shales are not equivalent due to differences in their sedimentological conditions (Huc et al., 1986). Hence no catalytic effect of clays on kerogen evolution could be discerned in the above maturity series, although this effect was often hypothesized in the past on the basis of laboratory experiments (Sieskind and Ourisson, 1972). Successful petroleum exploration in Tertiary deltaic settings around the world in the past twenty years, resulting in intensive geochemical studies on good quality cores and cuttings, showed that dispersed type III organic matter, whether associated with humic coals or not, is, like type II, an homogeneous and chemically well defined organic matter type, in contrast with type I deposits.

\subsubsection{The Main Steps of Kerogen Transformation on Burial and its Evolution Path in the van Krevelen Diagram}

Early diagenesis, from the death of living organisms up to deposition of mineral and organic debris as sediment and its

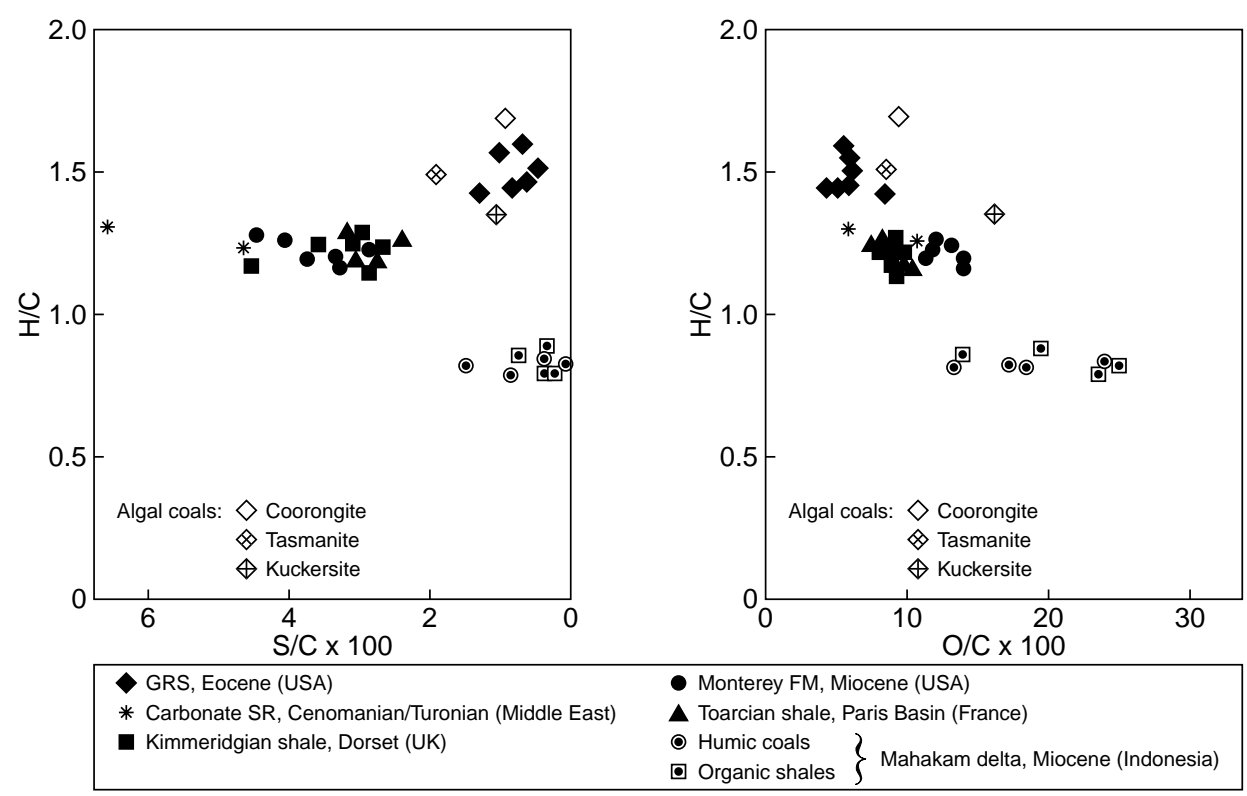

Figure 10

Elemental composition of immature kerogens in a double diagram of atomic ratios $\mathrm{H} / \mathrm{C}$ versus $\mathrm{O} / \mathrm{C}$ and $\mathrm{S} / \mathrm{C}$, showing the substantial incorporation of sulfur in marine organic matter, in contrast with S/C composition of lacustrine or continental organic matters (after Huc, 1990). 
burial to a few meters depth, is a step where biological processes have a major influence on the amount and composition of finally preserved organic matter. This step, during which the main loss of nitrogen occurs due to consumption of proteins, is not accounted for in the classical van Krevelen diagram. It is also the step for possible incorporation of sulfur in the organic matter, if sulfur bacterial colonies are present. The systematic incorporation of sulfur in marine kerogens is clearly seen (Fig. 10) in a diagram of elemental compositions of immature kerogens, derived from the van Krevelen representation and including organic sulfur (Huc, 1990). The presence of sulfates in seawater provides the oxidant source necessary for organic matter biodegradation by sulfate-reducing bacteria. These bacteria release polysulfides, $\mathrm{H}_{2} \mathrm{~S}$ and native sulfur capable of recombining both with iron from clays to ultimately form pyrite, and with the organic matter to produce organosulfur moieties (Aizenshtat et al., 1983). Preservation of organic matter during early diagenesis is strongly dependant on the oxygen content of water, a very low oxygen level (anoxia) strongly reducing the nature and efficiency of bacterial populations able to feed on organic debris during settling and early stages of sedimentation. Water circulation inside deposited sediments is also a factor controlling the bacterial

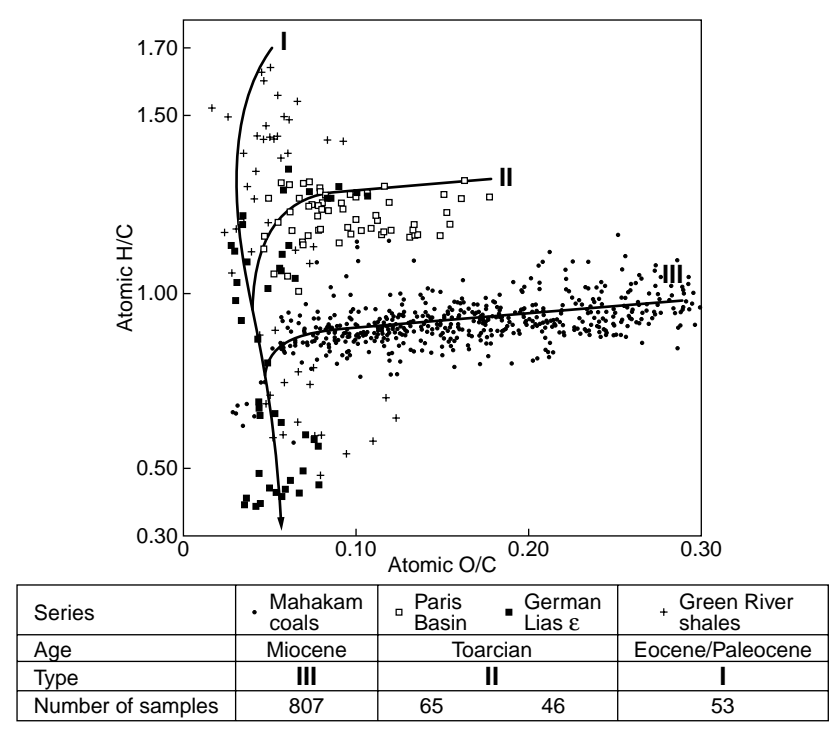

Figure 11

Comparison of elemental analyses from kerogens of the three main reference series, including many samples from Lias $\varepsilon$ from Germany (equivalent of the Toarcian of the Paris basin) with a very high maturity, and a coal series from the Mahakam delta covering a large maturity range (figure from Vandenbroucke et al., 1993, copyright Éditions Technip). destruction of organic matter. If water transported bacteria can freely circulate into the sediment porosity, which is the case in sands for example, the major part of the sedimented organic debris will be consumed. It is for this reason that high porosity reservoir rocks do not contain kerogen. The opposite situation is found for clays, not only because they may protect the organic matter by physicochemical adsorption, but also because their structure settles as "house of cards", increasing water pressure in the porosity and preventing water input during further compaction on burial. That explains why source rocks containing kerogen are for the most part fine grained sediments.

Diagenesis stricto sensu is a step where kerogen looses large amounts of oxygen, mainly as $\mathrm{CO}_{2}$ and $\mathrm{H}_{2} \mathrm{O}$ (see Fig. 8). This step is all the more evident if the initial kerogen is rich in oxygen, and is thus mainly observed for type III organic matter, but it is also significant for type II as seen on Figure 11. In this figure a large number of elemental analyses on one reference series for each kerogen type has been reported, including the Mahakam series as type III, not yet available when Figure 9 from Tissot and Welte (1978) was published. The Mahakam coal series was used here, because kerogen preparation on very immature samples was observed to changes elemental analysis due to hydrolysis of humic compounds. It can be noticed on this series that the evolution path starts at higher $\mathrm{H} / \mathrm{C}$ and the variation between the two successive steps is more marked than previously reported in the trend from the Mannville and Logbaba series.

Catagenesis is the main step of hydrogen (and carbon) loss from the kerogen, and is consequently the stage of petroleum formation. Considering a general formula of generated hydrocarbons as $\left(\mathrm{CH}_{2}\right) \mathrm{n}$, two $\mathrm{H}$ atoms are lost for one $\mathrm{C}$ atom, thus the atomic $\mathrm{H} / \mathrm{C}$ of the residual kerogen decreases in the van Krevelen diagram, reflecting an increasing aromatization. It appears immediately that the petroleum potential deduced from the $\mathrm{H} / \mathrm{C}$ variation range decreases strongly in the order from type I to type III. However commercial oil pool formation is not directly correlated to $\mathrm{H} / \mathrm{C}$ in source rocks, because it depends also on thermodynamic and geological parameters related to the nature of generated products and their ability to migrate to existing traps. As shown by natural extract and oil analyses from petroleum case studies and thermal simulations, compounds with lighter and lighter molecular weights are formed during this stage, leading finally to gases. An insoluble aromatic residue similar to coke is generated in late steps of catagenesis as the result of secondary cracking of petroleum products issued from kerogen. This residue, which has almost no petroleum potential, can be observed alone as "pyrobitumen" in high temperature reservoirs, but is also formed in source rocks and thus mixed with the residual kerogen.

The transition between catagenesis and metagenesis zones is located for all kerogen types at an atomic $\mathrm{H} / \mathrm{C}$ ratio 
Type I H/C = 0.49

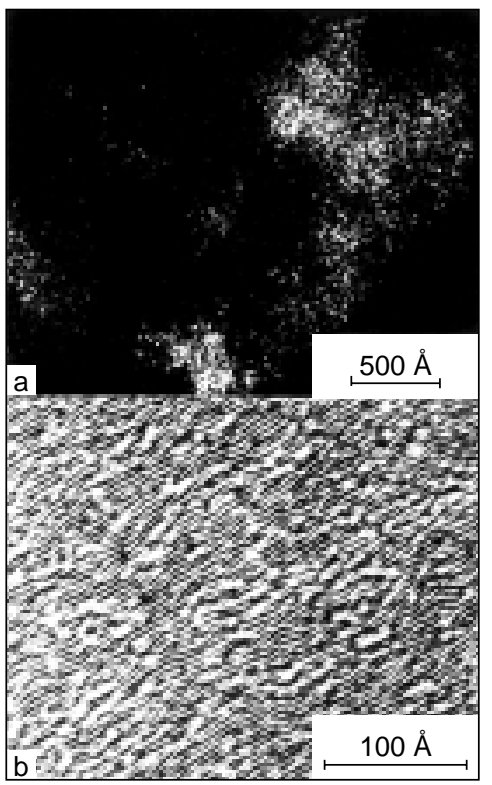

Type II H/C = 0.44

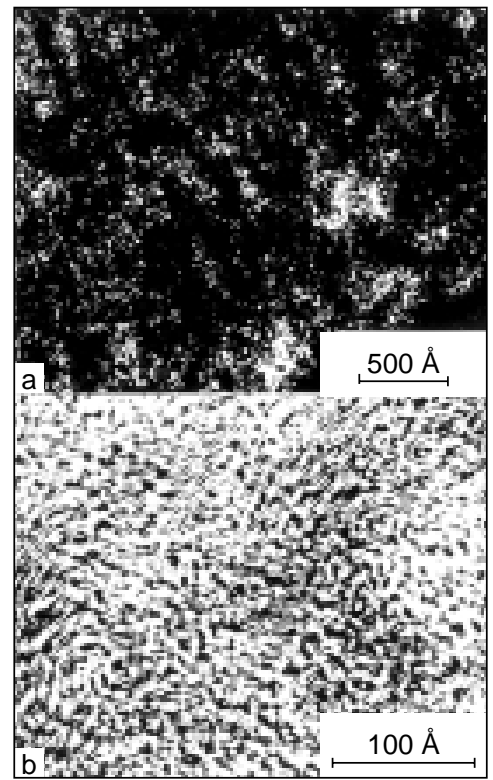

Type III H/C = 0.45

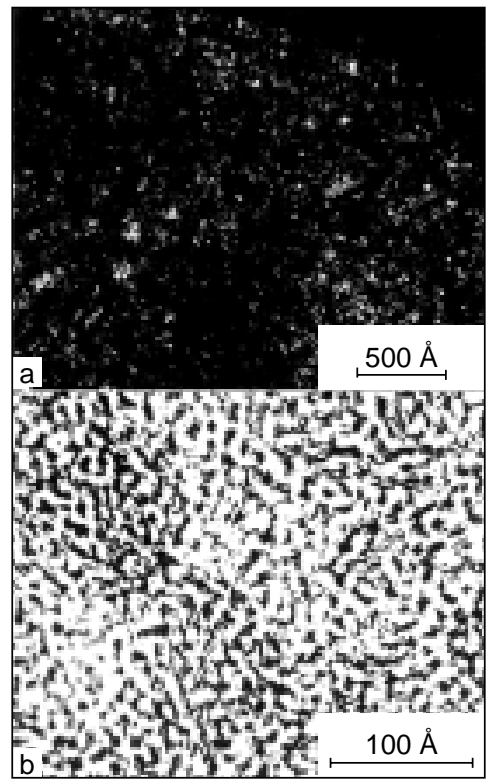

Figure 12

Comparison of the orientation of aromatic domains in the three kerogen types at high maturity, as observed with electron microscopy. (a) 00.2 dark field picture of aromatic domains (electrons diffracted by aromatic stacks). The diameter of aromatic stacks correspond to less than 10 condensed rings, piled up by 2 or 3 layers whatever the initial kerogen type. (b) 00.2 lattice fringes from aromatic domains seen edge on, showing that long distance orientation of aromatic domains depends on the initial kerogen type, with respectively for types I, II et III, average distances of $1000 \AA, 250 \AA$ and $100 \AA$ (after Oberlin et al., 1980).

around 0.6. Below this transition zone, all kerogen types defined by their elemental analysis merge into a single group. Metagenesis is the last stage of kerogen reorganization into an almost pure carbon structure. During this step, the aromatic lattice rearranges by expelling its "defects" in a manner similar to crystal formation. However, this rearrangement does not imply a substantial condensation of aromatic cycles but more a parallelization of existing aromatic structural units comprising less than 10 condensed rings into stacks associated by pi bonds, as seen by diffractometric techniques (Fig. 12) using transmission electron microscopy (Oberlin et al., 1980). The size of domains is still, contrary to elemental analysis, a characteristic of kerogen types because it depends on the mobility of kerogen aromatic domains during catagenesis, and thus on the amount of products expelled as oil. The free radical content in kerogen, which increases continuously during the catagenesis step, reaches its maximum and then decreases, as shown on type III kerogens from the Douala basin (Fig. 13) using electron paramagnetic resonance (Marchand and Conard, 1980). The first eliminated product is late methane, also called dry gas, resulting from release of methyl groups on aromatics.

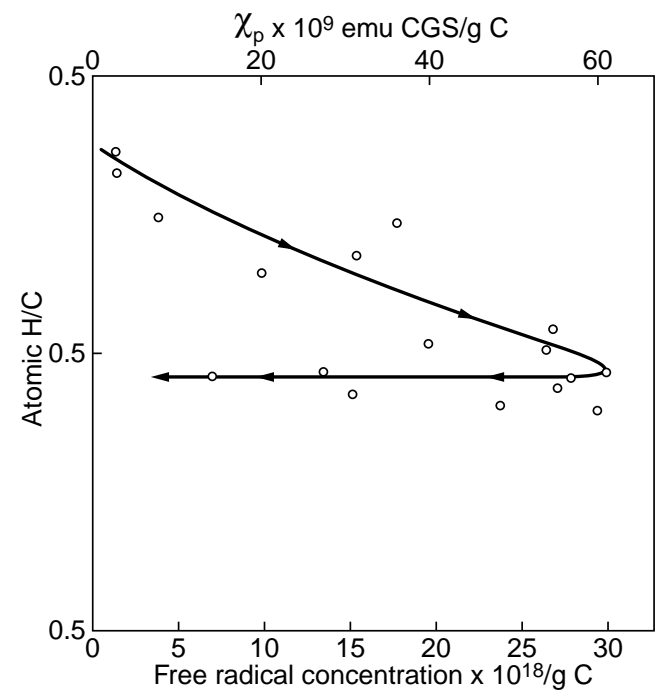

Figure 13

Evolution with increasing maturity of the concentration of free radicals in kerogens of the Logbaba series, as measured by electron paramagnetic resonance (after Marchand and Conard, 1980). 
Pyrolysis of mature kerogens of all types was shown to generate the same amount of late methane, around $50 \mathrm{mg}$ per $\mathrm{g}$ of kerogen (Béhar et al., 1997). This means that the amount of methyl groups on aromatics is similar in residual kerogens whatever their initial type, and it is thus only the amount of residual kerogen left after catagenesis, higher in a type III than in a type I series, that makes terrestrial kerogens and coals good source rocks for dry gas. Nonhydrocarbon gases are also formed during metagenesis by elimination of heteroelements from resistant bonds ( $\mathrm{O}$ from ethers) or from aromatic structures $\left(\mathrm{S}, \mathrm{N}, \mathrm{O}\right.$ ). Gases such as $\mathrm{CO}_{2}, \mathrm{H}_{2} \mathrm{O}, \mathrm{H}_{2} \mathrm{~S}$ and $\mathrm{N}_{2}$ were observed in both deep gas reservoirs and pyrolysis experiments (Lorant and Béhar, 2002).

\subsection{The Evolution of Research in the IFP Geochemistry Department from 1979 to 1990}

Year 1979 corresponds to the date on which B. Tissot left the IFP Geochemistry Department to take the responsibility of the IFP Scientific Direction. At this time the Geochemistry Department research focused on two main topics. One of them was to improve the kinetic schemes of oil and kerogen cracking, in order to include them into integrated petroleum system models. These latter aimed at reconstructing the sediment deposition, burial history and heat flow during geological time, and at calculating, from the cracking model, the amount of oil generated, the timing of its expulsion out of the source rock and its further migration and accumulation into traps. A second topic was to better understand the mechanisms of kerogen formation, in close relation with their depositional environment. It was thus necessary to follow the deposition and chemical transformation of kerogen during all steps of its geological maturation and not only during oil formation, in order to decipher the key factors of source rock formation. Accordingly, recent sediments were studied using soil science methodology, including among others isolation and analysis of humic substances, and particularly functional analysis, to understand their relationship to kerogen.

Analytical techniques had offered many new developments at this time, particularly gas chromatography for which the manufacturing of silica capillary columns with bonded phases allowed higher final temperatures and a much better peak resolution. New detectors, specific to molecular families of compounds including atoms of sulfur or nitrogen, were also developed or improved. Moreover, coupling of gas chromatography with mass spectrometry became at this time a widespread laboratory apparatus, due to the relatively low price of quadrupolar spectrometers, enabling molecular analysis of separate hydrocarbon families in complex mixtures such as petroleum compounds. Significant advances were also obtained in pyrolysis techniques for the molecular identification and quantification of building blocks of kerogen. This was achieved either by direct coupling of the pyrolysis system to the injection port of a gas chromatograph, or by preparation of pyrolysates, separated and studied in the manner described in Section 2.2.2 for extracts. Finally, major advances in organic analysis of solids resulted from developments in solid state ${ }^{13} \mathrm{C} \mathrm{NMR}$, enabling the quantitative analysis of carbon bond types in kerogen, as reported in Section 2.3. The resulting quantification of molecular building blocks and their bonding functional groups in kerogens thus made it possible to propose conceptual molecular models of kerogens as described below.

\section{BUILDIN G KEROGEN CONCEPTUAL MODELS}

\subsection{Why Conceptual Models?}

It appears clearly that given the complex macromolecular structure of kerogen, comprising both resistant biomacromolecules and recombined biodegradation products, any detailed chemical model represents only an averaged structure. To fix ideas, a detailed chemical structure which can be drawn on a single page, with a molecular mass around 25000 , makes an incredibly small amount of substance since the corresponding weight (by division by Avogadro's number) represents $4.10^{-20} \mathrm{~g}$ of kerogen. Any analytical technique used for kerogen characterization works on amounts in the microgram to milligram range, thus any analytical result is already an average on a large number of kerogen macromolecules. Thus a "real" representation of the chemical structure of kerogen has no meaning and only conceptual models representing at best the largest possible set of physicochemical analytical data, but including also many assumptions, can be obtained.

Although it is very difficult to describe such complex macromolecular mixtures by detailed chemical structures, many structural or chemical models of sedimentary organic matter were published in the past. Their aim was to visualize a number of its properties or analyses in a synthetic form to interpret or understand others. Thus a model aimed at representing physical or spectral properties can be a structural model whereas a model for describing chemical interactions or cracking reactions will rather be a molecular model. This rationale is very similar to that of petroleum system modeling, and in the same way the weighting and detail of input and output data will depend on the use for which these models are constructed. The first molecular models of sedimentary organic matter were built by coal scientists as early as 1942 by Fuchs and Sandhoff; then many other coal models based on an increasing number of analytical results from different techniques were built (Given, 1960; Spiro, 1981; Spiro and Kosky, 1982; Shinn, 1984; Solomon, 1981). Models for other types of sedimentary organic matter were constructed first for oil shales such as the Green River shale (Burlingame et al., 1968; Yen., 1976; 
Siskin et al., 1995), then for the three main types of kerogen at various maturity stages (Béhar and Vandenbroucke, 1986, 1987). Finally, the development of computerized molecular modelling enabled to build 3D molecular models satisfying not only bond lengths and directions (Faulon et al., 1990) but also minimum energy configurations (Kowalewski et al., 1996).

Building computerized chemical models of kerogen structures may be helpful as a guide to understanding the main chemical characteristics of sedimentary organic matter, and to predicting its evolution during geological burial. Although it will never be possible to represent a true kerogen structure, because it is a mixture of various nonpolymeric macromolecules that cannot be analyzed separately, such models of average kerogen structure, by accounting for a great amount of information from various analyses, can provide a synthetic view of the main resemblances and differences among sedimentary organic matters. They may be used for comparison of organic matter types and evolution during burial, modeling of cracking and compositional yields in source rocks, evaluation of retention or expulsion of petroleum and gas as a function of the thermal maturity and related thermodynamic properties of the mobile fraction.

\subsection{The Analyses used for Modeling and their Classification}

\subsubsection{Atomic Analyses}

We will define as atomic analyses those providing quantitative information on the number of atoms, their chemical environment or their spatial distribution. For example elemental analysis, solid state ${ }^{13} \mathrm{C}$ nuclear magnetic resonance (NMR) and more generally all spectroscopic analyses, density or lattice fringe imaging with electron microscopy, are classified as atomic analyses. They are performed on the kerogen itself, characterizing a subset of its macromolecular constituents, and thus provide average structural or chemical parameters.

\subsubsection{Molecular Analyses}

Molecular analyses qualify and quantify small building blocks of a complex structure. They are performed on degradation products of macromolecular kerogen constituents. Either chemical degradation, by oxidation for example, or thermal degradation, both by laboratory pyrolysis (pyrolysates) and by thermal cracking in geological conditions (extracts and oils), provide some of these building blocks. The rationale for analysing degradation products and in the ideal case cracking products, the structure of which is very close to its initial counterpart in kerogen, is that their structure is small enough to be characterized by a number of analytical techniques that cannot be used for solids. Degradation products must be small molecules in order to be identified as precisely as possible, ideally at the molecular scale. However they must retain as much as possible the molecular information present in kerogen macromolecules, and thus they should not be too small. In addition, the information they carry, both qualitative and quantitative, depends directly on the yield of products obtained with the degradation procedure, and the representativity of building blocks in regard to the source macromolecule is clearly not the same if the degradation yield is 5 or $80 \%$.

\subsection{Structural Models of Kerogen Types and Evolution}

Once quantitative atomic and molecular analyses are obtained on a given kerogen, the quantitative combination of molecular building blocks should ideally fit atomic data. The reality is not so simple because some information is still lacking and many hypotheses have to be made, not only on the types of bonding sites, but also on missing or incomplete data. The reverse situation can also occur, with two different techniques normally giving the same information in fact providing different analytical results. In such situations, one data set is chosen or the data is adapted on the basis of general knowledge on sedimentary organic compounds from the literature.

The main differences in structural components of kerogens according to their type at the onset of the oil window were first described in Vandenbroucke (1980) based on the composition of extracted bitumens. A structure for type II kerogen constituents was reported by Oberlin et al. (1980) in another chapter of the same book, using the complementary data of these authors on kerogen structural blocks, but as presented could not represent a kerogen because the building blocks had not been connected by bonds. However it was a starting point for trying to build a complete series of structures representing the three kerogen types at the main stages of their geological evolution. These structures were built by trial and error, using measured atomic and molecular parameters at the beginning of diagenesis, beginning of catagenesis (whole petroleum potential) and end of catagenesis (whole gas potential). The starting molecular weight was chosen on the basis of two constraints:

- insolubility in usual organic solvents, the limit being fixed by the measured molecular weight of dissociated asphaltene units, lower than 5000 dalton;

- the necessity to draw a kerogene structure large enough to account for statistically measured parameters, but small enough to be represented on paper and allow a reasonable number of atoms to be counted (not more than 3000).

The three kerogen type structures were thus represented with a similar number of carbon atoms around 1500 at the diagenesis stage, corresponding to molecular weights ranging from 20000 to 25000 dalton. Note that, as previously 

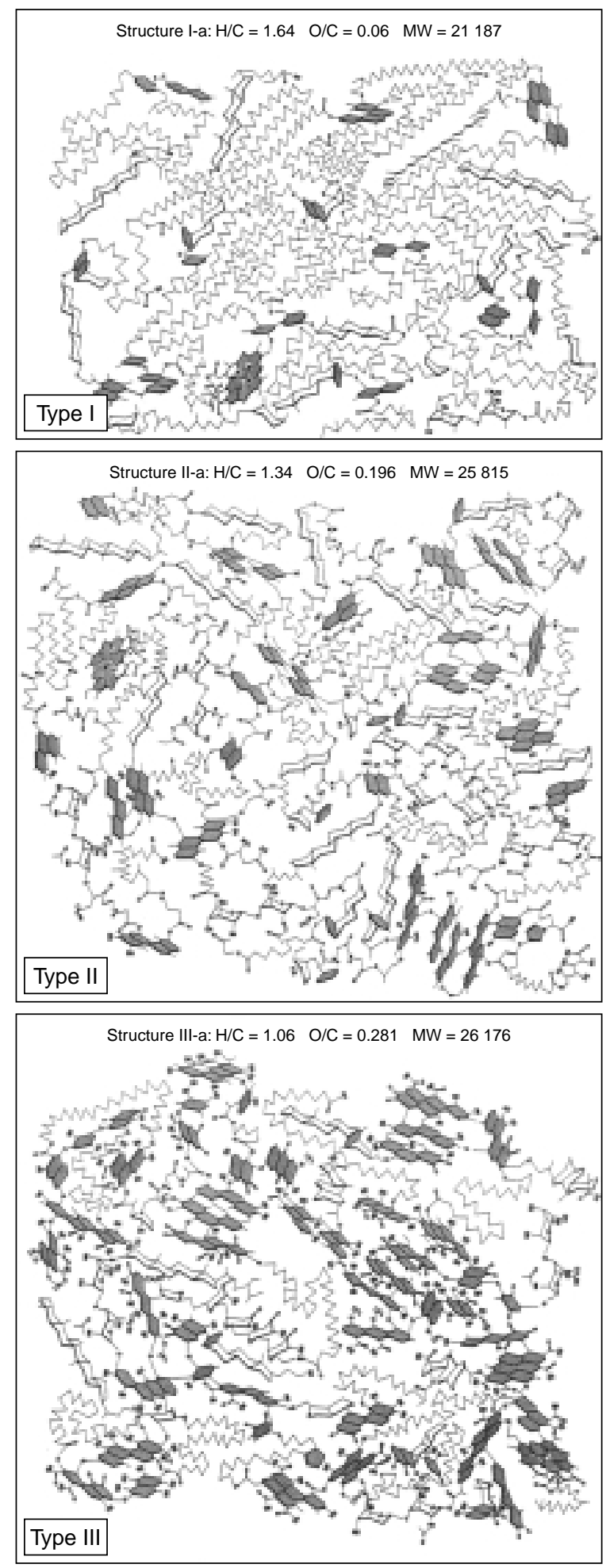

Figure 14

Structural models of kerogens: comparison of the chemical composition of kerogen types I, II and III at the beginning of diagenesis stage (after Béhar and Vandenbroucke, 1986).
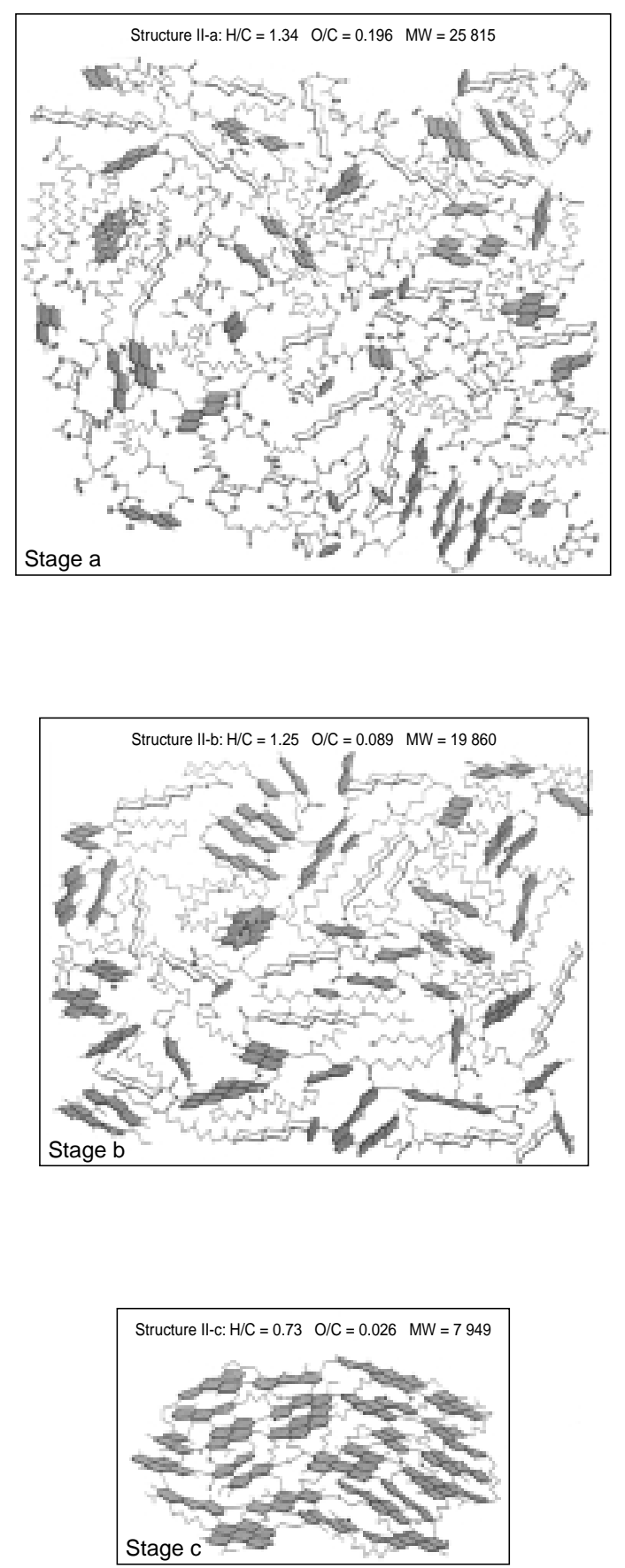

Figure 15

Structural models of kerogens: evolution of the chemical composition of type II kerogen at the evolution stages.

a: beginning of diagenesis stage;

b: beginning of catagenesis stage (beginning of oil generation);

c: end of catagenesis stage (beginning of gas generation) (after Béhar and Vandenbroucke, 1986). 
remarked, this corresponds to a very small weight of kerogen (around $4.10^{-17} \mathrm{mg}$ ) which cannot be analysed by any chemical technique. The size of the structure on maturation was constrained by the measured weight loss of each kerogen type during thermogravimetric analysis, i.e. $79 \%$ for type I, $62 \%$ for type II and 34\% for type III (Durand-Souron, 1980). The maximum number of condensed rings in aromatics and the orientation of aromatic clusters at the beginning of metagenesis were derived from dark-field imaging electron microscopy (Oberlin et al., 1980). Randomly selected molecular building blocks from molecular analyses and functional groups from chemical functional analysis were connected by covalent bonds in order to fit elemental analysis and solid state ${ }^{13} \mathrm{C}$ NMR results, removing or adding building blocks and functional groups to improve fitting of calculated and measured atomic parameters at each further step of the construction. As already noted, the idea was not to represent an exact chemical structure of kerogens since this cannot be analysed, but rather to show in a synthetic way their main chemical and physical characteristics related to type and maturity, in order to allow visual comparison, even for non chemists. Although trapping of saturates (Béhar and Vandenbroucke, 1988) and other bitumen constituents into the kerogen network had been demonstrated, these kerogen structures deliberately omitted trapped compounds since kerogen stricto sensu should be totally free of soluble compounds. The resulting structures were published in two papers, one depicting the three kerogen types at various maturity stages and their associated asphaltenes (Béhar and Vandenbroucke, 1986), the other dealing exclusively with kerogen structures (Behar and Vandenbroucke, 1987). A 3Dlike representation of individual cyclic building blocks was preferred to the traditional chemical representation in order to better visualize the differences in structure according to types and maturity. An example of the structures constructed for the three kerogen types at the beginning of diagenesis stricto sensu is shown on Figure 14. Structural transformations of type II kerogen at three increasing maturity stages, onset of diagenesis (stage a), onset of catagenesis (stage b) and end of catagenesis (stage c) is shown on Figure 15. The main structural parameters of all constructed models, fitting the analytical data of corresponding kerogen samples, are given in Table 2.

Given the tedious procedure of trial and error in assembling and counting molecular groups and bonding sites, then correcting them according to atomic data, a systematic construction and comparison of several structures fitting analyses of a given kerogen was not possible. Moreover, although the structural constituents (molecular building blocks, functional groups and bond types) can be predicted from analyses, the number of possible combinations of these elements is extremely large, and only a few models can be constructed. Computer-aided modeling was considered to help in this problem, and also in providing a more realistic view of structures by building 3D kerogen models. A computational tool for such macromolecules being not commercially available at this time, it was elaborated during a doctoral study (Faulon, 1991). Starting from the atomic and molecular analytical data previously described and from corresponding 3D structures of building blocks and bonds constructed in a library, the nature and total amount of the latter were first calculated to fit analyses. Further computation was simplified using intermediate building blocks and bonds where equivalent carbon configurations replaced heteroelements. Then, 3D carbon skeletons of kerogens were constructed by successively connecting these building blocks and bonds randomly selected from the library, assuming that any building block is connected by one or two covalent bonds. Finally, kerogen models were obtained by substituting carbons by heteroelements according to their corresponding atomic and functional analyses. A possible structure thus obtained for a type III kerogen at the end of catagenesis is shown on Figure 16. The microporosity observed in this structure is not an input constraint; it results exclusively from the construction with building blocks respecting bond lengths and directions.

TABLE 2

Main structural characteristics of kerogen models and associated natural samples corresponding to the following evolution stages: a: beginning of diagenesis; b: beginning of catagenesis (beginning of oil generation); c: end of catagenesis (beginning of gas generation)

\begin{tabular}{l|c|c|c|c|c|c|c|c|c}
\hline Kerogen & at. H/C & at. O/C & $\begin{array}{c}\text { MW } \\
\text { (dalton) }\end{array}$ & $\begin{array}{c}\text { Aliphatic C } \\
(\% \text { of tot. C) }\end{array}$ & $\begin{array}{c}\text { Naphthenic C } \\
(\% \text { of tot. C) }\end{array}$ & $\begin{array}{c}\text { Aromatic C (fa) } \\
(\% \text { of tot. C) }\end{array}$ & $\begin{array}{c}\text { Av. condensed } \\
\text { ring number }\end{array}$ & $\begin{array}{c}\text { Main funct. } \\
\text { group }\end{array}$ & $\begin{array}{c}\text { O in main f.g. } \\
(\% \text { of tot. O) }\end{array}$ \\
\hline Type I-a & 1.64 & 0.06 & 21187 & 74 & 12 & 14 & 1.9 & Ether \\
Type I-c & 0.83 & 0.013 & 4024 & 36 & $\varepsilon$ & 64 & 3.8 & Ether & 50 \\
\hline Type II-a & 1.34 & 0.196 & 25815 & 51 & 19 & 30 & 2.8 & Ester & 31 \\
Type II-b & 1.25 & 0.089 & 19860 & 45 & 14 & 41 & 3.1 & Ester \\
Type II-c & 0.73 & 0.026 & 7949 & 28 & $\varepsilon$ & 72 & 4.5 & Ether & 60 \\
\hline Type III-a & 1.06 & 0.281 & 26176 & 38 & 13 & 49 & 3 & Phenol & 25 \\
Type III-b & 0.98 & 0.138 & 18939 & 34 & 6 & 60 & 3.4 & Phenol & 32 \\
Type III-c & 0.67 & 0.059 & 13226 & 19 & $\varepsilon$ & 81 & 5.7 & Ether & 34 \\
\hline
\end{tabular}




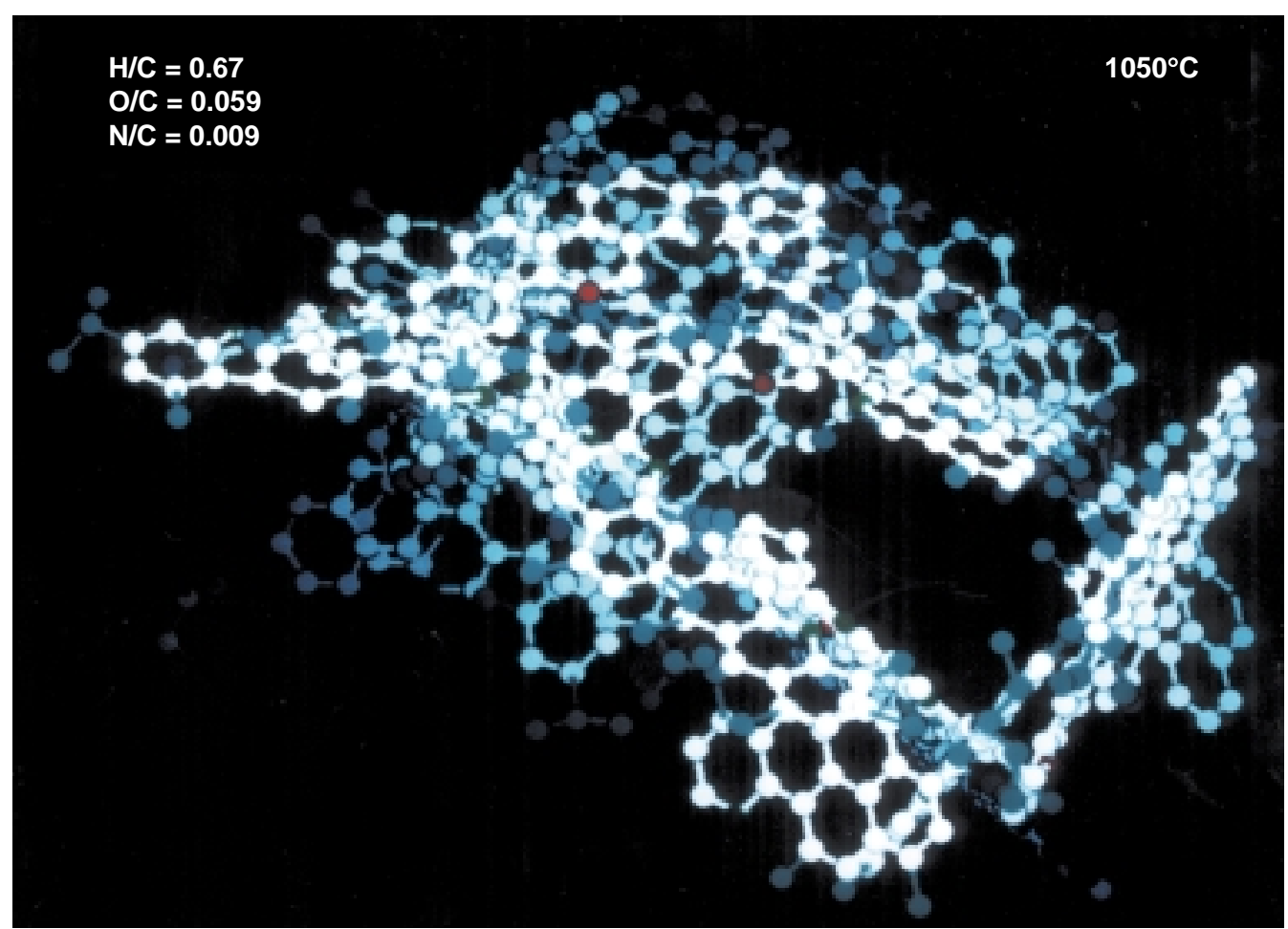

Figure 16

3D molecular structure of type III kerogen types at the evolution stage c: end of catagenesis. The energy is not minimized, but this is expected to make little difference due to the high aromaticity of this structure.

\section{CONCLUSIONS}

The increasing number of geochemical studies on petroleum systems raised in some cases questions as to the attribution of a defined type to specific source rocks, and these ambiguities were reflected by the frequent association of two types (I/II or II/III) to account for some of the measured geochemical parameters. The proposition of such associations is clearly not in line with the initial aim of characterizing sedimentary organic matter both by its original organic material and its depositional environment, as expressed by Tissot and Welte (1978, p. 142). The classification of kerogens based on reference types defined by their position in a van Krevelen diagram has indeed been of great help for oil exploration in predicting the petroleum generative capacity of source rocks and in describing the chemical characteristics of the generated oils. The notions of kerogen types and evolution paths, even though they may appear as an oversimplification of unique environmental situations, enabled a great deal of geochemical data to be condensed and explained in a simple manner to non geochemists. By achieving this, geochemistry secured a major position among the tools for oil and gas exploration. It should also be recalled that kerogen classification and association to specific depositional environments was at the source of major petroleum discoveries, and particularly those sourced by terrestrial organic matter.

In view of the extensive knowledge acquired on kerogen formation during the nearly twenty years following publication of kerogen models, thanks to studies of new samples and, more importantly, the new developments of analytical tools, one can today question their representativity. For example, the type I model presented here is likely valid only for kerogens corresponding to alkaline depositional environments similar to those occurring for the Green River Shale sedimentation. For type I organic matter resulting from eutrophication conditions, the microbial population and hence its chemical composition should be closely related to changes in the environment chemistry. Even among the Green River samples, a fairly large variability of the chemical analysis from immature kerogens was indeed observed (Tissot et al., 1978), both laterally and vertically. This is also true when comparing type I kerogens from the Green River shale to Botryococcus-derived type I kerogens, the structure of which has been the subject of numerous studies (Béhar et al., 1995, and references therein). In the case of type I paraffinic moieties, a large fraction of long chain constituents such as those observed by high temperature gas chromatography, although nonextractable with usual solvents, is probably only trapped by physical 
entanglement or steric hindrance and not linked by covalent bonds to the kerogen structure. The type II model could have a broader representativity, up to a certain limit of sulfur content. On the contrary, the molecular representation of coals and type III kerogens by averaged chemical structures cannot be realistic. In fact it was shown early on, by light microscopy observation of coals (Stopes, 1935), that their main constituents are physically completely separated at the microscopic level, thus implying separation at the macromolecular level. Given the common precursors of coals and type III kerogens, a similar problem should occur for the latter (Vandenbroucke, 1980). Accordingly, the organic fraction is mostly made up of ligneous debris with a predominantly aromatic structure, and a variable minor proportion of constituents derived from the protective tissues of higher plants, with a predominantly aliphatic structure rich in long chain alkanes. This double contribution from organic remains explains the apparent discrepancy observed between the mostly aromatic kerogen composition, as seen by elemental analysis with an atomic $\mathrm{H} / \mathrm{C}$ ratio lower than 1 , and the highly paraffinic extracts and oils generated by this type III kerogen, in comparison with type II generated products. Separation between aromatic lignous components and aliphatic debris from leaf and fruit membranes may also explain in part the very early generation and migration of heavy saturates in oils sourced by some type III kerogens, as observed in several case studies (Khorasani and Michelsen, 1991; Clayton et al., 1991).

Further advances in kerogen knowledge can still be expected in the coming years from new developments in analytical techniques. However many unknowns will remain for a long time regarding the atomic structural arrangement in kerogen moieties, in part because microscopic techniques at the atomic level need to be developed and adapted to such a study, and also because the onset of kerogen formation is mainly governed by biological processes, particularly biodegradation of living organic matter, the mechanisms of which still need many years of research to be understood.

\section{ACKN O W LEDG EMEN TS}

I gratefully acknowledge the pertinent comments of Françoise Béhar, Alain-Yves Huc, John Lynch and Bernard Colletta, that greatly improved earlier versions of the manuscript.

Major advances in the concepts and analytical tools described in this paper were achieved within the IFP Geochemistry Department. I participated from the beginning of my professional career in many of the research projects conducted by such eminent scientists as Bernard Tissot, Bernard Durand, Régis Pelet and many other colleagues from this department, and thus it is both a duty and a pleasure for me to dedicate this review to them.

\section{REFEREN CES}

Acholla, F.V., Orr, W.L. (1993) Pyrite removal from kerogen without altering organic matter: the chromous chloride method. Energy and Fuels, 7, 406-410.

Aizenshtat Z., Stoler, A., Cohen, Y, Nielsen, H. (1983) The geochemical sulphur enrichment of recent organic matter by polysulfides in the Solar-lake. In: Bjoroy, M. et al. (eds.) Advances in Organic Geochemistry 1981, Wiley, Chichester, 279-288.

Albrecht, P. (1969) Constituants organiques de roches sédimentaires. PhD Thesis, Strasbourg University.

Albrecht, P., Vandenbroucke, M., Mandengué, M. (1976) Geochemical studies on the organic matter from the Douala Basin (Cameroon) - I. Evolution of the extractable organic matter and the formation of petroleum. Geochimica et Cosmochimica Acta, 40, 791-799.

Béhar, F., Pelet, R. (1985) Pyrolysis-gas chromatography applied to organic geochemistry. Structural similarities between kerogens and asphaltenes from related rock extracts and oils. Journal of Analytical and Applied Pyrolysis, 8, 173-187.

Béhar, F., Vandenbroucke, M. (1986) Représentation chimique de la structure des kérogènes et des asphaltènes en fonction de leur origine et de leur degré d'évolution. Oil \& Gas Science and Technology - Rev. IFP, 41, 173-188.

Béhar, F., Vandenbroucke, M. (1987) Chemical modelling of kerogens. Organic Geochemistry, 11, 15-24.

Béhar, F., Vandenbroucke, M. (1988) Characterization and quantification of saturates trapped inside kerogen: implications for pyrolysate composition. In: Mattavelli, L., Novelli, L. (Eds.), Advances in Organic Geochemistry 1987, Organic Geochemistry, 13, 927-938.

Behar, F., Leblond, C., Saint-Paul, C. (1989) Analyse quantitative des effluents de pyrolyse en milieu ouvert et fermé. Oil \& Gas Science and Technology - Rev. IFP, 44, 387-411.

Béhar, F., Derenne, S., Largeau, C. (1995) Closed pyrolyses of the isoprenoid algaenan of Botryococcus braunii, L race: geochemical implications for derived kerogens. Geochimica et Cosmochimica Acta, 59, 2983-2997.

Behar, F., Vandenbroucke, M., Tang, Y., Marquis, F., Espitalié, J. (1997) Thermal cracking of kerogen in open and closed systems: determination of kinetic parameters and stoichiometric coefficients for oil and gas generation. Organic Geochemistry, 26, 321-339.

Béhar, F., Beaumont, V., De B. Penteado, H.L. (2001) Rock-Eval 6 technology: Performances and developments. Oil \& Gas Science and Technology - Rev. IFP, 56, 111-134.

Bordenave, M., Combaz, A., Giraud, A. (1970) Influence de l'origine des matières organiques et de leur degré d'évolution sur les produits de pyrolyse du kérogène. In: Hobson, G.D. and Speers, G.C. (eds.) Advances in Organic Geochemistry 1966, Pergamon Press, Oxford, 389-405.

Boudou, J.P. (1981) Diagenèse organique de sédiments deltaïques (delta de la Mahakam, Indonésie). PhD Thesis, Orleans University.

Burlingame, A.L., Haug, P.A., Schnoes, H.K., Simoneit, B.R. (1969) Fatty acids derived from the Green River Formation oil shale by extractions and oxidations - A review. In: Schenck, P.A., Havenaar, I. (eds.), Advances in Organic Geochemistry 1968, Pergamon Press, Oxford, 85-129.

Clayton, J.L., Rice, D.D., Michael, G.E. (1991) Oil-generating coals of the San Juan Basin, New Mexico and Colorado, USA Organic Geochemistry, 17, 735-742. 
Combaz, A., De Matharel, M. (1978) Organic sedimentation and genesis of petroleum in Mahakam delta, Borneo. AAPG Bulletin, 62, 1684-1695.

Crum-Brown, A. (1912) Oil shales of the Lothians. Memoirs Geological Survey, 143.

Deroo, G., Durand, B., Espitalié, J., Pelet, R., Tissot, B. (1969) Possibilité d'application des modèles mathématiques de formation du pétrole à la prospection dans les bassins sédimentaires. In: Schenck, P.A., Havenaar, I. (Eds.) Advances in Organic Geochemistry 1968, Pergamon Press, Oxford, 345-353.

Deroo, G., Powell, T.G., Tissot, B., McCrossan, R.G.(1977) The origin and migration of petroleum in the Western Canadian sedimentary basin, Alberta - A geochemical and thermal maturation study. Geological Survey of Canada, Bulletin 262.

Deroo, G., Powell, T.G. (1978) The oil sands deposits of Alberta: their origin and geochemical history. In: Strausz, O.P., Lown, E.M. (Eds.) Oil Sand and Oil Shale Chemistry, Verlag Chemie International, New York, 11-32.

Dunoyer de Segonzac, G. (1969) Les minéraux argileux dans la diagenèse. Passage au métamorphisme. PhD Thesis, Strasbourg University.

Durand, B., Espitalié, J. (1970) Analyse géochimique de la matière organique extraite des roches sédimentaires. II. Extraction et analyse quantitative des hydrocarbures de la fraction $\mathrm{C}_{1}-\mathrm{C}_{15}$ et des gaz permanents. Oil \& Gas Science and Technology - Rev. IFP, 25, 741-751.

Durand, B., Espitalié, J., Oudin, J.L. (1970) Analyse géochimique de la matière organique extraite des roches sédimentaires. III. Accroissement de la rapidité du protocole opératoire par l'amélioration de l'appareillage. Oil \& Gas Science and Technology - Rev. IFP, 25 1268-1279.

Durand, B., Espitalié, J. (1971) Formation et évolution des hydrocarbures de $\mathrm{C}_{1}$ à $\mathrm{C}_{15}$ et des gaz permanents dans les argiles du Toarcien du bassin de Paris. In: von Gaertner, H.R. and Wehner H. (Eds.), Advances in Organic Geochemistry 1971, Pergamon Press, Oxford, 455-468.

Durand, B., Espitalié, J., Nicaise, G., Combaz, A. (1972) Étude de la matière organique insoluble (kérogène) des argiles du Toarcien du Bassin de Paris. I - Étude par les procédés optiques, analyse élémentaire, étude en microscopie et diffraction électroniques. Oil \& Gas Science and Technology - Rev. IFP, 27, 865-884.

Durand, B., Espitalié, J. (1973) Évolution de la matière organique au cours de l'enfouissement des sédiments. Comptes rendus de l'Académie des Sciences, 276, 2253-2256.

Durand, B., Espitalié, J. (1976) Geochemical studies on the organic matter from the Douala Basin (Cameroon) -II. Evolution of kerogen. Geochimica et Cosmochimica Acta, 40, 801-808.

Durand, B. (Ed.) (1980) Kerogen, Insoluble Organic Matter from Sedimentary Rocks. Éditions Technip, Paris.

Durand, B. (1980) Sedimentary organic matter and kerogen. Definition and quantitative importance of kerogen, in Durand, B. (ed.), Kerogen, Insoluble Organic Matter from Sedimentary Rocks. Éditions Technip, Paris, 13-34.

Durand, B., Nicaise, G. (1980) Procedures of kerogen isolation, in Durand, B. (Ed.), Kerogen, Insoluble Organic Matter from Sedimentary Rocks. Éditions Technip, Paris, 35-53.

Durand, B., Monin, J.C. (1980) Elemental analysis of kerogens, in Durand, B. (Ed.), Kerogen, Insoluble Organic Matter from Sedimentary Rocks, Éditions Technip, Paris, 113-142.

Durand, B., Oudin, J.L. (1980) Exemple de migration des hydrocarbures dans une série deltaique: le delta de la Mahakam, Kalimantan, Indonésie. In: $10^{\text {th }}$ World Petroleum Congress Proceedings vol. 2, Heyden, London, 3-11.
Durand-Souron, C.(1980) Thermogravimetric analysis and associated techniques applied to kerogens. In: Durand, B. (Ed.), Kerogen, Insoluble Organic Matter from Sedimentary Rocks. Éditions Technip, Paris, pp.143-161.

Durand-Souron, C., Boulet, R., Durand, B. (1982) Formation of methane and hydrocarbons by pyrolysis of immature kerogens. Geochimica et Cosmochimica Acta, 46, 1193-1202.

Ehmann, W.D., Koppenhaal, D.W., Hamrin Jr., C.E., Jones, W.C., Prasad, M.N., Tian, W.Z. (1986) Comparison of methods for the determination of organic oxygen in coals. Fuel, $\mathbf{6 5}, 1563$ 1570.

Espitalié, J., Durand, B., Roussel, J.C., Souron, C. (1973) Étude de la matière organique insoluble (kérogène) des argiles du Toarcien du Bassin de Paris. II - Étude en spectroscopie infrarouge, en analyse thermique différentielle et en analyse thermogravimétrique. Oil \& Gas Science and Technology - Rev. IFP, 28, 37-66.

Espitalié, J., Laporte, J.L., Madec, M., Marquis, F., Leplat, P., Paulet, J., Boutefeu, A. (1977a) Méthode rapide de caractérisation des roches mères, de leur potentiel pétrolier et de leur degré d'évolution. Oil \& Gas Science and Technology - Rev. IFP, 32, 23-42.

Espitalié, J., Madec, M., Tissot, B., Mennig, J.J., Leplat, P. (1977b) Source rock characterization method for petroleum exploration. Offshore Technology Conference, Paper OTC 2935, 439-444.

Espitalié, J., Senga Makadi, K., Trichet, J. (1984) Role of the mineral matrix during kerogen pyrolysis. Advances in Organic Geochemistry 1983. Organic Geochemistry, 6, 365-382.

Faulon, J.L., Vandenbroucke, M., Drappier, J.M., Béhar, F., Romero, M.. (1990) 3D chemical model for geological macromolecules. Organic Geochemistry, 16, 981-993.

Faulon, J.L. (1991) Prediction, elucidation et modélisation moléculaire: algorithmes et applications. PhD Thesis.

Fester, J.I., Robinson, W.E. (1966) Oxygen functional groups in Green River oil-shale kerogen and trona acids. In: Gould, R.F., (Ed.), Coal Science, ACS Publications, Washington D.C., 22-31.

Forsman, J.P. (1963) Geochemistry of kerogen, in Breger, I.A. (Ed.), Organic Geochemistry, Earth Series, monograph no. 16, Pergamon Press, Oxford, 148-182.

Forsman, J.P., Hunt, J.M. (1958) Insoluble organic matter (kerogen) in sedimentary rocks. Geochimica et Cosmochimica Acta, 15, 170-182.

Fuchs, W., Sandhoff, A.G. (1942) Theory of coal pyrolysis. Industrial and Engineering Chemistry, 34, 567-571.

Giraud, A. (1970) Application of pyrolysis and gas chromatography to geochemical characterization of kerogen in sedimentary rock. AAPG Bulletin, 54, 439-455.

Given, P.H. (1960) The distribution of hydrogen in coals and its relation to coal structure. Fuel, 39, 147-153.

Hatcher, P.G. (1980) The origin, composition, chemical structure and diagenesis of humic substances, coals and kerogens as studied by nuclear magnetic resonance. PhD Thesis, University of Maryland.

Huc, A.Y. (1978) Geochimie organique des schistes bitumineux du Toarcien du bassin de Paris. PhD Thesis, University of Strasbourg.

Huc A.Y., Durand B., Roucache J., Vandenbroucke M., Pittion J.L. (1986) Comparison of three series of organic matter of continental origin. In: Leythaeuser, D., Rullkotter, J. (Eds.), Advances in organic geochemistry 1985. Organic Geochemistry 10, $1 / 3,65-72$. 
Huc, A.Y. (1990) Understanding organic facies: a key to improved quantitative petroleum evaluation of sedimentary basins. In: Huc, A.Y. (Ed.), Deposition of Organic Facies, AAPG Studies in Geology, 30, AAPG Publications, Tulsa, Oklahoma, pp. 1-11.

Khavari Khorasani, G., Michelsen, J.K. (1991) Geological and laboratory evidence for early generation of large amounts of liquid hydrocarbons from suberinite and subereous components. Organic Geochemistry, 17, 849-863.

Klemme, H.D., Ulmishek, G.F. (1991) Effective petroleum source rocks of the world: stratigraphic distribution and controlling depositional factors. AAPG Bulletin, 75, 1809-1851.

Kowalewski, I., Vandenbroucke, M., Huc, A.Y., Taylor, M.J., Faulon, J.L. (1996) Preliminary results on molecular modeling of asphaltenes using structure elucidation programs in conjunction with molecular simulation programs. Energy \& Fuels 10, 97-107.

Lafargue, E., Béhar, F. (1989) Application of a new preparative pyrolysis technique for the determination of source-rock types and oil/source-rock correlation. Geochimica et Cosmochimica Acta, 53, 2973-2983.

Lafargue, E., Marquis, F., Pillot, D. (1998) Rock-Eval 6 applications in hydrocarbon exploration, production, and soil contamination studies. Oil \& Gas Science and Technology - Rev. IFP, 53, 421-437.

Larsen, J.W., Pan, C.S., Shawver, S. (1989) Effect of demineralization on the macromolecular structure of coals. Energy \& Fuels, 3, 557-561.

Leplat, P., Noël, R. (1972) Étude par pyrochromatographie en phase gazeuse et par réflectance de l'évolution de quelques kérogènes. In: von Gaertner, H.R. and Wehner H. (Eds.), Advances in Organic Geochemistry 1971, Pergamon Press, Oxford, 567-576.

Leplat, P., Noël, R. (1974) Contribution à l'étude de l'état de diagenèse des roches à kérogène par le dosage automatique rapide du $\mathrm{CO}_{2}$ et du $\mathrm{C}_{2} \mathrm{H}_{4}$ libérés par pyrolyse de 400 à $900{ }^{\circ} \mathrm{C}$. In: Tissot, B. and Bienner, F. (Eds.), Advances in Organic Geochemistry 1973, Éditions Technip, Paris, 107-115.

Lorant, F., Béhar, F. (2002) Late generation of methane from mature kerogens. Energy \& Fuels, 16, 412-427.

Louis, M. (1966) Études géochimiques sur les schistes cartons du Toarcien du Bassin de Paris, in Hobson, G.D. and Louis, M.C. (Eds.), Advances in Organic Geochemistry 1964, Pergamon Press, Oxford, 85-94.

Louis, M., Tissot, B. (1967) Influence de la température et de la pression sur la formation des hydrocarbures dans les argiles à kérogène. $7^{\text {th }}$ World Petroleum Congress Proceedings, 2 , Elsevier, Amsterdam, 47-60.

Maciel, G.E., Bartuska, V.J., Miknis, F.P. (1979) Characterization of the organic material in coal by protondecoupled nuclear magnetic resonance with magic angle spinning. Fuel, 58, 391-394.

Mc Iver, R.D. (1967) Composition of kerogen - clue to its role in the origin of petroleum. $7^{\text {th }}$ World Petroleum Congress Proceedings, 2, Elsevier, Amsterdam, 25-36.

Marchand, A., Conard, J. (1980) Electron paramagnetic resonance in kerogen studies. In: Durand, B. (Ed.), Kerogen, Insoluble Organic Matter from Sedimentary Rocks. Éditions Technip, Paris, 243-270.

Monin, J.C., Durand, B., Vandenbroucke, M., Huc, A.Y. (1980) Experimental simulation of the natural transformation of kerogen, in Douglas, A.G. and Maxwell, J.R. (Eds.), Advances in Organic Geochemistry 1979, Pergamon Press, Oxford, 517-530.

Oberlin, A., Boulmier, J.L., Villey, M. (1980) Electron microscopic study of kerogen microtexture. Selected criteria for determining the evolution path and evolution stage of kerogen.
In: Durand, B. (Ed.), Kerogen, Insoluble Organic Matter from Sedimentary Rocks. Editions Technip, Paris, 191-241.

Oudin, J.L., Califet-Debyser, Y. (1969) Influence of depth and temperature on the structure and distribution of alkanes and aromatic hydrocarbons from rock extracts. In: American Chemical Society Division of Petroleum Chemistry PreprintsNew York 1969 Meeting, ACS Publications, Washington D.C., 16-21.

Oudin, J.L. (1970) Analyse géochimique de la matière organique extraite des roches sédimentaires. I. Composés extractibles au chloroforme. Oil \& Gas Science and Technology - Rev. IFP, 25, 3-15.

Pelet, R. (1987) Vue d'ensemble sur les résultats du sondage Misedor. In: Le sondage Misedor, Editions Technip, Paris, 375383.

Robinson, W.E. (1969) Isolation procedures for kerogens and associated soluble organic materials. In: Eglinton, G., Murphy, M.T.J. (Eds.). Organic Geochemistry - Methods and Results. Springer -Verlag, Berlin Heidelberg New York, 181-195.

Saxby, J.D. (1970) Isolation of kerogens in sediments by chemical methods. Chemical Geology, 6, 173-184.

Shinn, J.H. (1984) From coal to single-stage and two-stage products: a reactive model of coal structure. Fuel, 63, 1187-1196.

Sieskind, O., Ourisson, G., 1972. Hydrocarbures formés par le craquage thermocatalytique de l'acide stéarique en présence de montmorillonite. Comptes rendus de l'Académie des Sciences, 274, 2186-2189.

Siskin, M., Scouten, C.G., Rose, K.D., Aczel, T., Colgrove, S.G., Pabst Jr., R.E. (1995) Detailed structural characterization of the organic material in Rundle Ramsay Crossing and Green River oil shales. In: Snape, C., (Ed.), Composition, Geochemistry and Conversion of Oil Shales, Kluwer Academic Publishers, Dordrecht, 143-158.

Solomon, P.R. (1981) New approaches in coal chemistry. In: ACS Symposium Series 169, Washington, 61-71.

Souron, C., Boulet, R., Espitalié, J. (1974) Etude par spectrométrie de masse de la décomposition thermique sous vide de kérogènes appartenant à deux lignées évolutives distinctes. Oil \& Gas Science and Technology - Rev. IFP, 24, 661-678.

Souron, C., Boulet, R., Espitalié, J. (1977) Étude par spectrométrie de masse de la décomposition thermique de roches sédimentaires contenant de la matière organique de deux types différents et comparaison avec les kérogènes correspondants. In: Advances in Organic Geochemistry 1975, Campos R. and Goni, Y. (Eds.), 797-820.

Spiro, C.L. (1981) Space-filling models for coal: a molecular description of coal plasticity. Fuel, 60, 1121-1126.

Spiro, C.L., Kosky, P.G. (1982) Space-filling models for coal. 2. Extension to coals of various ranks. Fuel, 61, 1080-1087.

Stankiewicz, B.A., Kruge, MA, Crelling, J.C., Salmon, G.L. (1994) Density gradient centrifugation: application to the separation of macerals of Type I, II and III sedimentary organic matter. Energy \& Fuels, 8, 1513-1521.

Stopes, M. (1935) On the petrology of banded bituminous coals. Fuel, 14, 4-13.

Tissot, B., Califet-Debyser, Y., Deroo, G., Oudin, J.L. (1971) Origin and evolution of hydrocarbons in early Toarcian shales, Paris basin, France. AAPG Bulletin, 55, 2177-2193.

Tissot, B. (1969) Premières données sur les mécanismes et la cinétique de la formation du pétrole dans les sédiments Simulation d'un schéma réactionnel sur ordinateur. Oil \& Gas Science and Technology - Rev. IFP, 24, 470-501.

Tissot, B., Pelet, R. (1971) Nouvelles données sur les mécanismes de genèse et de migration du pétrole - Simulation 
mathématique et application à la prospection. In: $8^{\text {th }}$ World Petroleum Congress Proceedings, 2, Applied Science Publishers, London, 35-46.

Tissot, B., Durand, B., Espitalié, J., Combaz, A. (1974) Influence of nature and diagenesis of organic matter in formation of petroleum. AAPG Bulletin, 58, 499-506.

Tissot, B., Espitalié, J., 1975. L'évolution thermique des sédiments : applications d'une simulation mathématique. Oil \& Gas Science and Technology - Rev. IFP, 30, 743-777.

Tissot, B., Deroo, G, Hood, A. (1978) Geochemical study of the Uinta Basin: formation of petroleum from the Green River formation. Geochimica et Cosmochimica Acta, 42, 1469-1485.

Tissot, B., Vandenbroucke, M. (1983) Geochemistry and pyrolysis of oil shales. In: Miknis, F.P., McKay, J.F. (eds.), Geochemistry and Chemistry of Oil Shales, ACS Symposium Series 230, 1-11.

Tissot, B.P., Welte, D.H., (1978) Petroleum Formation and Occurrence, Springer Verlag, Berlin.

Vandenbroucke, M., Albrecht, P., Durand, B. (1976) Geochemical studies on the organic matter from the Douala Basin (Cameroon) - III. Comparison with the early Toarcian shales, Paris basin, France. Geochimica et Cosmochimica Acta, 40, 1241-1249.

Vandenbroucke, M., Durand, B., Hood, A. (1977) Thermal evolution experiments on a kerogen from the Green River Shales formation. Publication to Advances in Organic Geochemistry 1977, Moscow. IFP report no. 25168.

Vandenbroucke, M. (1980) Structure of kerogens as seen by investigations on soluble extracts. In: Durand, B. (Ed.), Kerogen, Insoluble Organic Matter from Sedimentary Rocks, Éditions Technip, Paris, 415-443.

Vandenbroucke, M., Durand, B., Oudin, J.L. (1983) Detecting migration phenomena in a geological series by means of $\mathrm{C}_{1}-\mathrm{C}_{35}$ hydrocarbon amounts and distribution. In: Bjoroy at al. (Eds.), Advances in Organic Geochemistry 1981, Wiley \& Sons, Chichester, 147-155.

Vandenbroucke, M., Béhar, F., Espitalié, J. (1988) Characterization of sedimentary organic matter by preparative pyrolysis: comparison with Rock-Eval pyrolysis and pyrolysis-gas chromatography techniques. Energy \& Fuels, 2, 252-258.

Vandenbroucke, M., Largeau, C. (2004) Kerogen formation, structure and evolution. Submitted to Organic Geochemistry.

van Krevelen, D.W. (1961) Coal: Typology - Chemistry - Physics - Constitution. Elsevier, The Netherlands.

Yen, T.F. (1976) Structural aspects of organic components in oil shales. In: Yen, T.F., Chilingarian, G.V. (Eds.) Oil Shale, Developments in Petroleum Science, 5, Elsevier, Amsterdam, 129-148.

Final manuscript received in March 2003 
